\title{
Therapeutic Strategies to Protect the Central Nervous System against Shiga Toxin from Enterohemorrhagic Escherichia coli
}

\author{
Jorge Goldstein ${ }^{1, *}$, Krista Nuñez-Goluboay ${ }^{1}$ and Alipio Pinto ${ }^{1, *}$ \\ ${ }^{I}$ Universidad de Buenos Aires, Consejo Nacional de Investigaciones Científicas y Técnicas (CONICET), Instituto de \\ Fisiología y Biofísica "Houssay" (IFIBIO), Laboratorio de Neurofisiopatología, Facultad de Medicina, Argentina
}

A R T I C L E H I S T O R Y
Received: January 15,2020
Revised: January 20,2020
Accepted: February 19,2020
DOI:
10.2174/1570159X18666200220143001

\begin{abstract}
Infection with Shiga toxin-producing Escherichia coli (STEC) may cause hemorrhagic colitis, hemolytic uremic syndrome (HUS) and encephalopathy. The mortality rate derived from HUS adds up to $5 \%$ of the cases, and up to $40 \%$ when the central nervous system (CNS) is involved. In addition to the well-known deleterious effect of Stx, the gram-negative STEC releases lipopolysaccharides (LPS) and may induce a variety of inflammatory responses when released in the gut. Common clinical signs of severe CNS injury include sensorimotor, cognitive, emotional and/or autonomic alterations. In the last few years, a number of drugs have been experimentally employed to establish the pathogenesis of, prevent or treat CNS injury by STEC. The strategies in these approaches focus on: 1) inhibition of Stx production and release by STEC, 2) inhibition of Stx bloodstream transport, 3) inhibition of Stx entry into the CNS parenchyma, 4) blockade of deleterious Stx action in neural cells, and 5) inhibition of immune system activation and CNS inflammation. Fast diagnosis of STEC infection, as well as the establishment of early CNS biomarkers of damage, may be determinants of adequate neuropharmacological treatment in time.
\end{abstract}

Keywords: Neurodegeneration, neuroprotection, neuropharmacology, reactive astrocytes, microvasculature, oligodendrocytes, microglial cells, Shiga toxin 2, images, brain, cerebellum, transmission electron microscopy, fluorescence microscopy, lipopolysaccharides, inflammation, Hemolytic Uremic Syndrome.

\section{INTRODUCTION}

Shiga-like toxins (Stx), also known as verotoxins [1], are a virulence factor released by enterohemorrhagic $E$. coli (EHEC) and non-EHEC bacteria, both generically called Shiga-toxin-producing E. coli (STEC) [2, 3].

Shiga toxins belong to an AB family of bacterial toxins, which includes tetanus (from Clostridium tetani), cholera (from Vibrio cholerae), anthrax (from Bacillus anthracis) and diphtheria toxins (from Corynebacterium diphtheriae), among others [4]. AB toxins are named after their two basic protein components: the catalytic A component exerts its action in intracellular molecules, while the $\mathrm{B}$ component is responsible for the binding of the toxin to specific receptors on target cells $[4,5]$. In the case of Stx (Fig. 1), the B subunit is a homopentamer-structure that recognizes the receptor globotriaosylceramide (Gb3).

The interaction between Stx and Gb3 is responsible for the hemolytic-uremic syndrome (HUS), a clinical syndrome which primarily targets children up to 5 years of age [6]. HUS

*Address correspondence to these authors at the Universidad de Buenos Aires, Consejo Nacional de Investigaciones Científicas y Técnicas (CONICET), Instituto de Fisiología y Biofísica "Houssay" (IFIBIO), Laboratorio de Neurofisiopatología, Facultad de Medicina, Argentina; E-mails: jogol@fmed.uba.ar; jorgoldstein@gmail.com and apinto@fmed.uba.ar; pintoalipio@gmail.com is a triad characterized by thrombocytopenia, microangiopathic hemolytic anemia and variable degrees of renal compromise, ranging from minor urine abnormalities to severe renal disease, which may be preceded by prodromal bloody diarrhea in STEC-infected patients [6-11]. STEC causes more than 2.8 million annual acute illnesses worldwide, leading to 3890 cases of HUS and 230 deaths [12]. The central nervous system (CNS) is frequently affected, producing an acute encephalopathy which is responsible for a worse prognosis. The mortality rate derived from HUS adds up to $5 \%$ of the cases, and up to $40 \%$ when the CNS is involved [13].

Stx genes are encoded within a chromosomally integrated lambdoid prophage genome [14-16]. Antibiotics promote Shiga toxin production by inducing the lithic cycle of the lambda bacteriophage, thus enhancing the replication and expression of Stx genes. For these reasons, the use of conventional antibiotics is contraindicated and even increases the risk of developing HUS [17]. At present, there is no consensus high-efficiency treatment for STEC infections [18]. In addition to Stx, STEC also releases lipopolysaccharides (LPS), the main component of the outer membrane of Gram-negative bacteria responsible for serogroup identification (O antigen) [5]. The frequent endotoxemia observed in HUS patients suggests an important role of LPS in STEC pathogenesis [19]. 

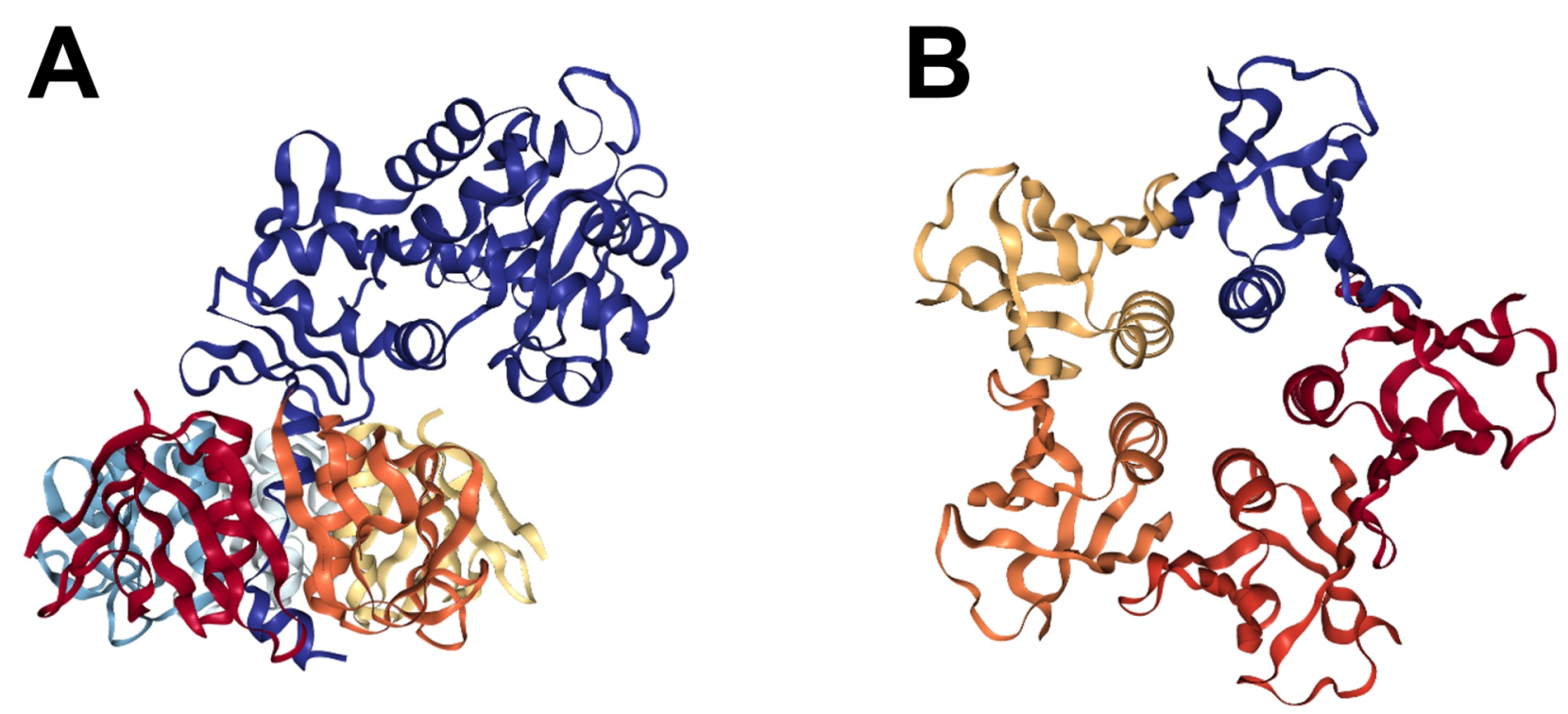

Fig. (1). Crystal structure of Shiga toxin. A: crystal structure of Shiga toxin. The A-subunit is shown in dark blue and the B-subunit is shown in different colors (PDB \#1R4P); B: Shiga toxin B-subunit with individual B-monomers is shown in different colors (PDB \#3MXG); PDB images were obtained from Research Collaboratory for Structural Bioinformatics Protein Data Base (www.rcsb.org). (A higher resolution / colour version of this figure is available in the electronic copy of the article).

STEC major reservoir is cattle; therefore, human infection is produced through the consumption of contaminated bovine-derived products, contaminated water, unpasteurized apple drinks and vegetables. STEC has a low infective dose; only 10 colony-forming units can produce an infection in humans, which allows potential direct transmission through contact with infected people or animals [20-23].

\section{STX MECHANISM OF ACTION}

Based on their serological neutralization profile, there are two main groups of Stx: Stx 1, which has a molecular mass of $70 \mathrm{kDa}$, and Stx2, which has $60 \mathrm{kDa}$ [24]. Each group, in turn, comprises various subtypes named in letters [25]. Stx 1 shows remarkable homology with Stx from Shigella dysenteriae. Furthermore, it can be neutralized by antibodies raised against Stx, as they differ in only one amino acid residue. On the other hand, Stx2 shows around 55\% homology with Shigella's toxin and cannot be neutralized by Shigella-raised antibodies [26]. Although the affinity of Stx 1 to its receptor is 10 -fold higher than that of Stx2, the latter has 400 -fold higher toxicity than Stx1 in mice [27] and is primarily responsible for severe cases in human infections [28-31].

The B subunit of Stx is a homopentameric protein noncovalently associated with the A subunit by its terminal carboxyl extreme $[4,32]$. The $\mathrm{B}$ homopentamer binds to the membrane receptor globotriaosylceramide $(\mathrm{Gb} 3)$, a glycosphingolipid present on a detergent-insoluble portion of lipid raft membranes rich in cholesterol [33].

Once the interaction of StxB-Gb3 occurs, it evokes an endocytic process which may be clathrin-dependent or independent $[34,35]$ and which culminates in a retrograde pathway that ends in the cytosol. Early endosomes containing Stx escape the lysosomal pathway to the trans-Golgi network and the Golgi apparatus to finally reach the endoplasmic reticulum. The A subunit contains a loop formed by a disul- fide bond involving two cysteines in positions 242 and 261 . This loop area contains the sequence Arg-X-X-Arg, which is enzymatically cleaved by furin in two different chains: A1, which has a molecular mass of $27.5 \mathrm{kDa}$, and $\mathrm{A} 2$, with a molecular mass of A2 $4.5 \mathrm{kDa}[33,36]$. These two chains remain linked by a disulfide bond. The A1 chain -which contains the catalytic N-glycosidase activity-subsequently translocates to the cell cytosol and removes the adenine residue 2260 of $28 \mathrm{~S}$ eukaryotic rRNA. Thus, protein synthesis is inhibited at the translational level as the elongation factor EIF2a no longer binds to ribosomes [37-39], which triggers a ribotoxic stress response of pro-apoptotic and proinflammatory events $[27,40]$ (Fig. 1).

$\mathrm{Gb} 3$ is heterogeneously distributed in the body. It may be found in endothelial cells, hematopoietic cells, pancreas, heart, liver, kidney and the CNS [8]. Although the Gb3 biological function has not been entirely elucidated yet, recent evidence suggests that it plays an essential role in protein reabsorption by renal proximal tubules [41]. Furthermore, $\mathrm{Gb} 3$ is the Pk antigen from the human P blood group system $[42,43]$ and the CD77 antigen associated to Burkitt's lymphoma [44]; it is also present in activated B-cells which undergo apoptosis after not being selected for plasma ce11 differentiation in germinal centers of lymphoid tissue [45].

$\mathrm{Gb} 3$ consists of a ceramide moiety composed of different fatty acid chains linked by an amide bond to a sphingosine, which, in turn, is linked to a sugar chain (galactose $\alpha 1-4$ galactose $\beta 1-4$ glucose). The ceramide element is composed by relatively constant sphingosine and a highly variable fatty acid chain which, depending on the cell type and the stage of the cell cycle, may show different lengths and degrees of saturation [46]. Therefore, there are many Gb3 isoforms whose fatty acid chain length and saturation degree influence the cytotoxic action of Stx, with long fatty acid chains being responsible for greater toxicity. The amount of cholesterol 
and phosphatidylcholine seems to be an important factor responsible for toxin internalization $[4,47,48]$. It has been reported that cholesterol microdomains enhance the binding and the entry of Stx [4], probably because cholesterol can modulate the orientation of the carbohydrate group of $\mathrm{Gb} 3$ [48].

Polymorphonuclear leukocytes (PMN), which do not express $\mathrm{Gb} 3$, have been reported to be the main carriers of Stx from the intestine to systemic organs [49-53]. Stx binds to PMN via the TLR4 receptor, which has a 100-fold lower affinity than the $\mathrm{Gb} 3$ receptor; however, pre-treatment with LPS induces a 30 -fold increase in specific binding sites for Stx on PMN [54].

Another non-canonical way in which Stx may act is through a delivery system in Stx-containing microvesicles from various types of cells. These microvesicles charged with Stx also have the intrinsic ability to induce thrombosis by activating coagulation factors, as they contain the activated complement components phosphatidylserine and tissue factor [55]. Free Stx in the bloodstream is almost undetectable, as it is either attached to blood cells or present in Stxcontaining microvesicles which have a cytotoxic effect equivalent to that of the free toxin.

Stx reaches the cerebral parenchyma by breaking the blood-brain barrier (BBB) [56]. However, alternative cerebral parenchyma routes of access should not be excluded, such as the blood-cerebrospinal fluid (CSF) barrier and circumventricular organs, i.e., structures located around the third and fourth ventricles characterized by a lack of the BBB.

Stx may also exert an important cytotoxic effect by inducing a strong inflammatory status. This is achieved through the activation of leukocytes, endothelial cells and the alternative pathway of complement, with the consequent production of reactive oxygen species (ROS) and the release of cytokines/chemokines. This secondary effect may be heightened by LPS and it may contribute to the physiopathology of the disease [57]. Furthermore, pro-inflammatory cytokines induced by LPS, such as TNF- $\alpha$, promote the upregulation of $\mathrm{Gb} 3$, which increases cellular sensitivity to Stx $[56,58]$. Clinical evidence supporting these events was found in patients with encephalopathy-derived STEC infections with elevated concentration of plasma TNF- $\alpha$, a soluble form of types I and II TNF receptor, neopterin, IL-8 and IL-6 $[59,60]$. It has also been shown that LPS non-responder mice treated with Stx2, together with LPS, have mild systemic symptoms with later isolated neurologic symptoms, in contrast with LPS responder mice, which develop a severe combination of gastrointestinal, neurologic and systemic symptoms. This indicates that the combination of Stx and LPS is a determinant contributor to the pathogenesis of the disease [61].

\section{STX AND THE HUMAN CNS}

The abnormal accumulation of metabolic products in circulation due to renal failure includes toxic compounds like creatinine and uric acid, among others, which may produce uremic encephalopathy leading to cognitive dysfunction, motor disorders and seizures [62]. During HUS, kidney damage correlates with an increase in these metabolites, although up to $15 \%$ of the patients positively diagnosed with STEC develop encephalopathy before the onset of HUS. This event supports the hypothesis that the cerebral damage in STEC infections may be produced directly by Stx in the neural tissue and not by a mere accumulation of metabolic products due to renal failure [63].

In humans, CNS symptoms of this disease are diverse, with patients suffering from blindness, hyperreflexia, deficits in orientation, attention or memory abilities, poor fine-motor coordination, seizures or irregular myoclonus and coma, among others [64-76]. Brain magnetic resonance images have also shown recurrent edema with hemorrhagic components, which indicates the presence of inflammation and vascular damage. These changes were observed in distinct brain areas such as basal ganglion, thalamus, midbrain, corpus callosum, cerebellum, white matter and brain stem [64-66, 68-73]. Furthermore, CSF analyses have shown an elevated protein concentration in 10 to $30 \%$ of patients. This fact is consistent with BBB disruption, as protein concentration in normal CSF is low compared to serum $[67,77]$.

In addition, post-mortem samples have shown edema and focal infarcts due to hypoxic/anoxic/ischemic events [77]. Focal microhemorrhages are often found together with hypoxic-ischemic changes throughout the brain. Although the pathophysiology of HUS involves small vessel occlusions, cerebral occlusive syndromes are not frequently reported. Very few histopathological findings have reported micro thrombosis in the CNS, which suggests the involvement of endothelial damage with no significant platelet or coagulation activation $[73,78]$.

In May 2011, an outbreak of STEC was reported in northern Germany, with a total of 53 associated deaths. According to the final report of the Robert-Koch-Institute [71], a total of 3842 patients were infected with STEC O104:H4, while 855 patients developed HUS and exhibited neurological symptoms in the seventh day after the onset of diarrhea. Neurological symptoms in these cases included double vision, difficulties in finding words, hyperreflexia, deficits in orientation, attention or memory abilities and seizures, among others. Almost $29 \%$ of those patients needed mechanical ventilation in the course of the disease due to severe alteration of consciousness. Furthermore, the severity of encephalopathy is usually accompanied by increased proinflammatory TNF- $\alpha$ and IL- $1 \beta$ cytokines, which suggests an important role of cytokines in the pathogenesis of the disease. Infection by STEC leads to the production of these cytokines not only in the intestine, but also in systemic circulation and in the brain [70]. In addition, in 2019, the Center for Disease, Control and Prevention (CDC) reported five outbreaks of STEC infection triggered by the intake of the following contaminated foods: fresh express sunflower crisp chopped salad kits, romaine lettuce, ground bison, flour and ground beef (https://www.cdc.gov/ecoli/2019/o103-0419/index.html)

\section{PHARMACOLOGY}

Although conservative therapy appears to be a wellaccepted treatment for HUS patients, no consensus therapy 


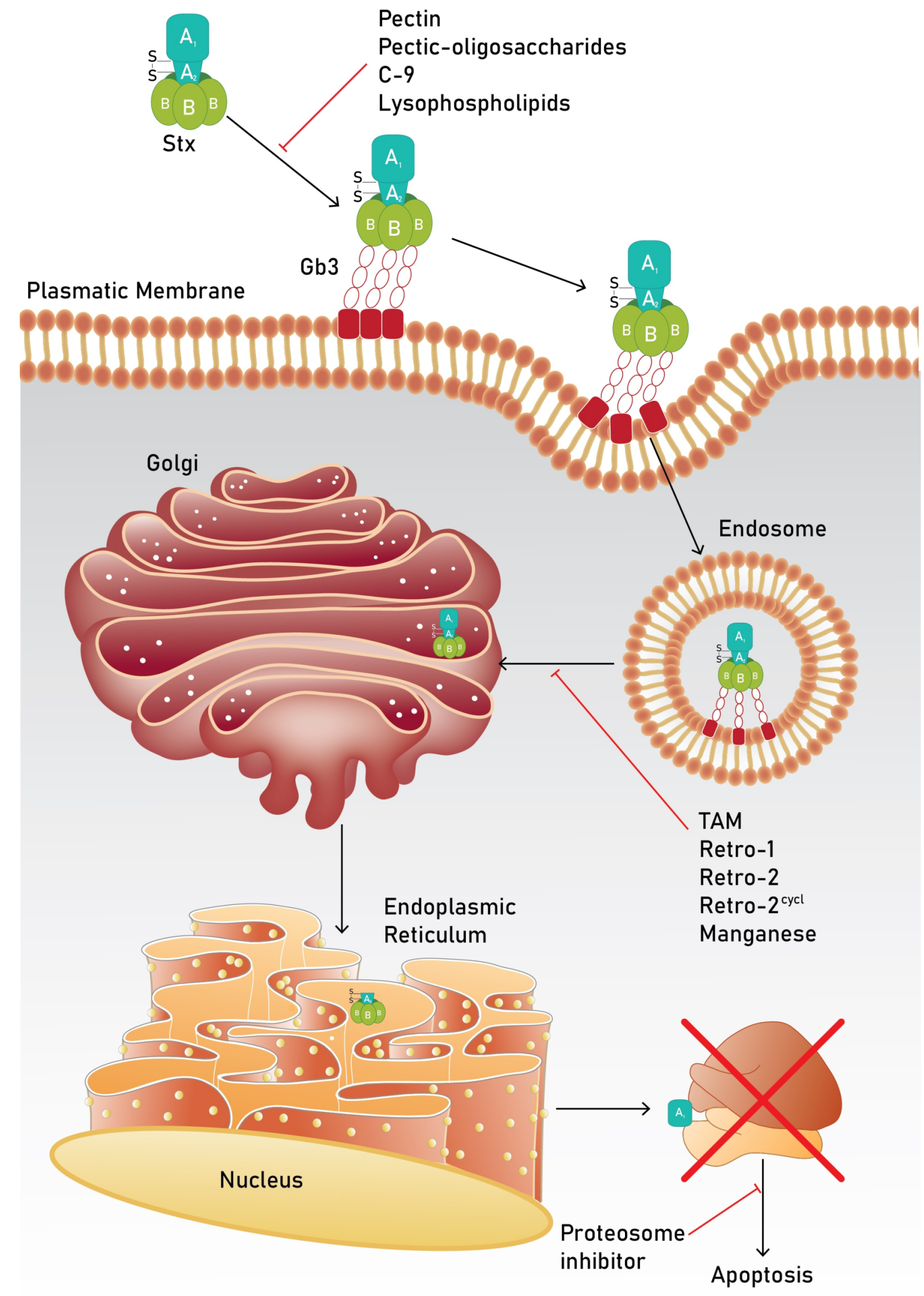

Fig. (2). Stx cellular pathway, action and therapeutic strategies to block it. Black arrows show Stx cellular pathway and action: binding of Stx to Gb3, endocytosis process, the retrograde pathway to trans-Golgi network and endoplasmic reticulum. A1 subunit reaches cytosolic ribosomes, inhibits protein synthesis and leads to apoptosis. Red blunt arrows show specific Stx pathway and action blocked by each therapeutic approach. (A higher resolution / colour version of this figure is available in the electronic copy of the article). 


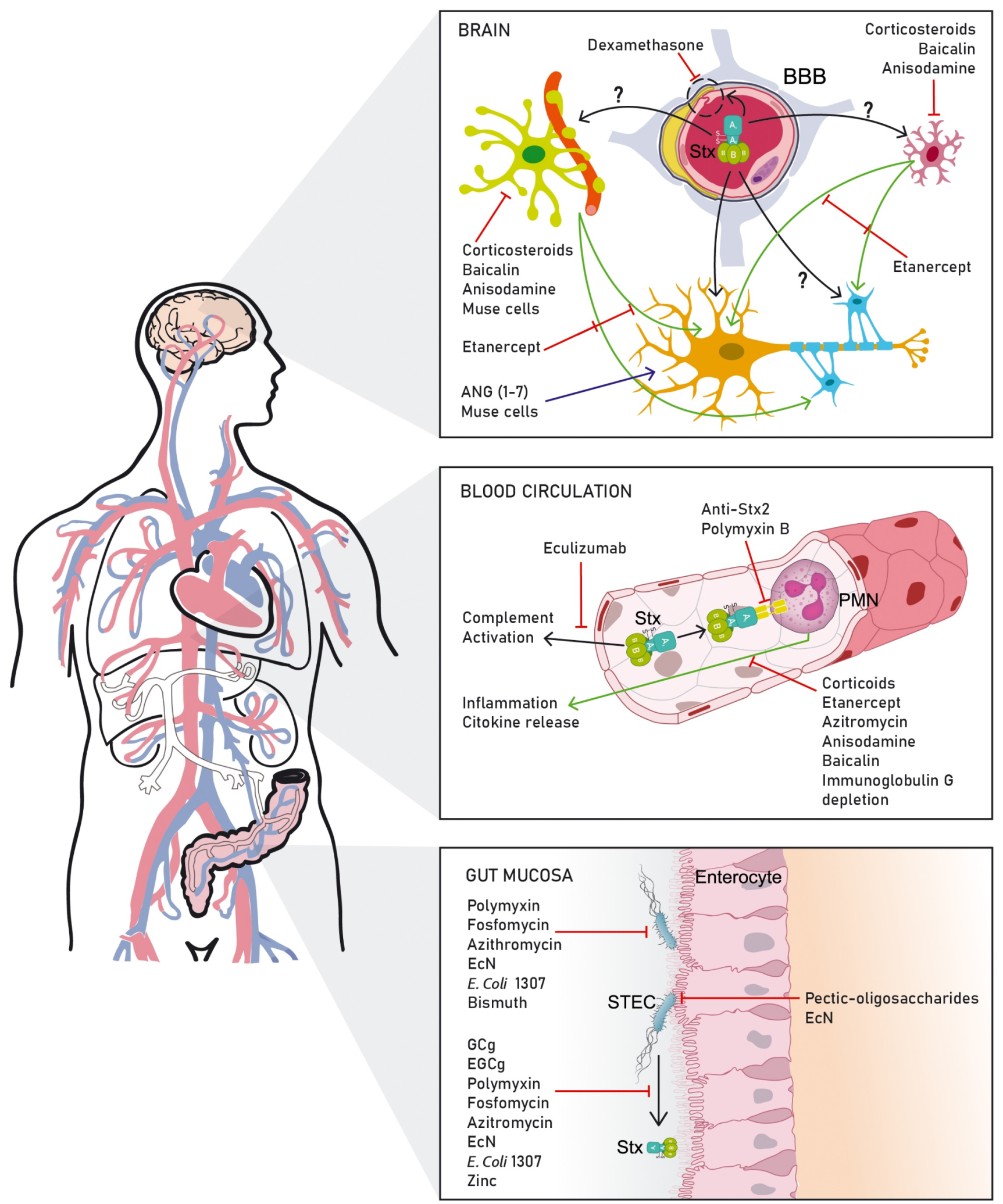

Fig. (3). Therapeutic strategies to protect the CNS against Shiga toxin. Black arrows show the consequences of STEC infection and the direct effects of Stx in the body. Question mark on black arrows suggests a cellular effect of Stx not described yet. Green arrows show the cell release of deleterious factors in response to Stx. Red blunt arrows show specific Stx pathway and action blocked by each therapeutic approach or an inhibitory effect of these drugs on STEC bacteria in the gut mucosa. Blue arrow shows drugs that produce their neuropharmacological action without blocking any specific Stx pathway or action. Green cell: astrocyte in contact with a vessel; red cell: microglia; blue cell: oligodendrocyte; orange cell: neuron. BBB: blood-brain-barrier; PMN: polymorphonuclear. (A higher resolution / colour version of this figure is available in the electronic copy of the article). 
Table 1. Brief description of the drugs analyzed in this review.

\begin{tabular}{|c|c|c|c|c|}
\hline Drug Class & Drug & Type of Study & Effect & Refs. \\
\hline \multirow{8}{*}{ Antibiotics } & \multirow{2}{*}{ Polymyxin B } & \multirow{2}{*}{ In vitro (human neutrophils) } & Inhibited the interacion of StxA with TLR4. & \multirow{2}{*}{ Carnicelli et al., 2016 [76] } \\
\hline & & & Inhibition of neutrophils activation. & \\
\hline & Polymyxin E (Colistin) & In vitro $($ E. coli $\mathrm{O} 157: \mathrm{H} 7)$ & Reduced in a dose-dependent manerthe release of Stx 2 and LPS. & Percivalle et al., 2016 [83] \\
\hline & Fosfomycin & Clinical study & Protected patients against Stx & Ikeda et al., 1999 [90] \\
\hline & \multirow{4}{*}{ Azythromycin } & In vitro $($ E. coli $\mathrm{O} 86: \mathrm{H}-)$ & Had a low MIC and inhibited Stx production & \multirow{4}{*}{ Ohara et al., 2002 [92] } \\
\hline & & $\begin{array}{l}\text { In vitro (Human mononuclear } \\
\text { cells) }\end{array}$ & Inhibited the Stx1/Stx2-stimulated cytokine production & \\
\hline & & In vivo (murine model) & Decreased in Stx-induced proinflamatory citokynes production & \\
\hline & & & Protected effect against Stx challenge & \\
\hline \multirow{16}{*}{$\begin{array}{l}\text { Anti- } \\
\text { inflammatory }\end{array}$} & \multirow{2}{*}{ Betamethasone } & \multirow{2}{*}{ In vivo (rabbit model) } & Reduced rabbit mortality & \multirow{2}{*}{ Fujii et al., 2009 [102] } \\
\hline & & & Protected rabbit against brain edema & \\
\hline & \multirow{8}{*}{ Methylprednisolone } & Case report & Reduced systemic proinflammatory cytokines & Oki et al., 2008 [104] \\
\hline & & Case roport & Patient recovered without any sequela & Yoshimitsu et al., 2011 [105] \\
\hline & & Case report & Improved the patient condition & Shimizu et al., 2014 [57] \\
\hline & & Clinical study & Patients recovered completely & Takanashi et al., 2014 [103] \\
\hline & & Case report & Patient condition improved gradually & Ito et al., 2015 [56] \\
\hline & & Case report & Improved the patient condition & Yada et al., 2015 [106] \\
\hline & & Clinical study & Increased the patients good outcome & Kuroda et al., 2015 [107] \\
\hline & & Case report & Patient recover without any sequela & Hosaka et al., 2017 [91] \\
\hline & \multirow{5}{*}{ Dexamethasone } & \multirow{5}{*}{ In vivo (murine model) } & increased the survival of mice challenged with a lethal doses of Stx2 & \\
\hline & & & Protected neuronal populations present in different brain regions & Pinto et al., 2013 [112] \\
\hline & & & Reduced astrocyte/microglial reaction \& damage to the myelin sheath & Pinto et al., 2017 [53] \\
\hline & & & Protected the BBB \& restored the basal expression of VEGF & Pinto et al., 2018 [113] \\
\hline & & & Reversed changes in mice behavior & \\
\hline & Etanercept & In vivo (rat model) & Reduced the Stx 2 uptake by neurons \& its lethal effect & Pinto et al., 2018 [113] \\
\hline \multirow{4}{*}{ Vasoactive drugs } & \multirow[t]{2}{*}{ Angiotensin 1-7 } & $\begin{array}{l}\text { In vitro (mixed glia mouse } \\
\text { culture) }\end{array}$ & Did not prevent oligodendrocyte damage & \multirow[t]{2}{*}{ Goldstein et al., 2016 [118] } \\
\hline & & In vivo (rat model) & Prevented Stx2-induced damage in neurons and oligodendrocytes & \\
\hline & \multirow[t]{2}{*}{ Anisodamine } & $\begin{array}{l}\text { In vitro (Human monocytic } \\
\text { cells) }\end{array}$ & Inhibited the production of TNF- $\alpha$, IL- $1 \beta$ and IL- 8 & \multirow[t]{2}{*}{ Zhang et al., 2000 [135] } \\
\hline & & In vivo (murine model) & Increased the survival of Stx 1-treated mice & \\
\hline \multirow{5}{*}{ Antibodies } & \multirow{5}{*}{ Eculizumab } & Clinical study & Improved the patient condition rapidly & Lapeyraque et al., 2011 [147] \\
\hline & & Clinical study & Produced a good neurological outcome & Gitiaux et al., 2013 [145] \\
\hline & & Case report & Produced an improvement of the patiant neurologic status & Saini et al., 2015 [149] \\
\hline & & Clinical study & Produced a good neurological outcome & Pape et al., 2015 [65] \\
\hline & & Review & Produced a positive improvement in patient condition & Mahat et al., 2019 [148] \\
\hline
\end{tabular}




\begin{tabular}{|c|c|c|c|c|}
\hline Drug Class & Drug & Type of Study & Effect & Refs. \\
\hline \multirow{7}{*}{ Antibodies } & \multirow{6}{*}{ Antibodys anti-Stx } & In vivo (murine model) & Protected mice challenged with a lethal charge of STEC and from Stx & $\begin{array}{l}\text { Yamagami et al., } 2001[160] \\
\text { Kimura et al., } 2002[158]\end{array}$ \\
\hline & & In vitro (ACHN cells) & Protected cells against Stx & Kimura et al., 2002 [158] \\
\hline & & In vivo (murine model) & Prevented the lethal effects of Stx & Santer et al., 2008 [161] \\
\hline & & In vivo (murine model) & Protected mice challenged with Stx & \multirow{2}{*}{ Mejias et al., 2016 [157] } \\
\hline & & In vitro (Vero cells) & Protected cells against Stx & \\
\hline & & $\begin{array}{l}\text { Phase } 1 \text { safety and phar- } \\
\text { macokinetic study }\end{array}$ & Were well tolerated by patients & $\begin{array}{l}\text { Dowling } 2005 \text { [162]; Bitzan } \\
2009 \text { [163]; Lopez } 2010 \text { [164] }\end{array}$ \\
\hline & Stx vaccine & In vivo (murine model) & $\begin{array}{l}\text { Protected mice challenge with a lehtal dose of Stx2 or lethal charge with } \\
\qquad \text { EHEC }\end{array}$ & $\begin{array}{l}\text { Mejias et al., } 2013[166] \\
\text { Mejias et al., } 2014 \text { [165] }\end{array}$ \\
\hline \multirow{6}{*}{ Polyphenols } & Polyphenols & In vitro (Vero cells) & Protected cells against Stx & Quinones et al., 2009 [172] \\
\hline & \multirow{4}{*}{ Baicalin } & In vitro (Vero cells) & Protected cells against Stx & Vinh et al., 2019 [176] \\
\hline & & In vitro (HELA cells) & Protected cells against Stx & $\begin{array}{l}\text { Dong et al., } 2015[174] \text {; } \\
\text { Zhang et al., } 2017[175]\end{array}$ \\
\hline & & In vivo (mice) & Protected mice challenged with Stx & Dong et al., 2015 [177] \\
\hline & & In vivo (mice) & Protected mice challenged with a lethal charge of E. coli O157:H7 & Zhang et al., 2017 [175] \\
\hline & Catechins & In vitro $($ E. coli $\mathrm{O} 157: \mathrm{H} 7)$ & inhibited bacteria growth and suppressed the release of Stx from STEC & $\begin{array}{l}\text { Sugita-Konishi et al., } 1999 \\
\text { [177] }\end{array}$ \\
\hline \multirow{5}{*}{ Pharmabiotics } & \multirow{2}{*}{ prebiotics } & $\begin{array}{l}\text { In vitro (Human HT29 } \\
\text { cells ) }\end{array}$ & Protected cells against Stx & $\begin{array}{l}\text { Olano-Martin et al., } 2003 \\
\qquad[189]\end{array}$ \\
\hline & & $\begin{array}{l}\text { In vitro (Human HT29 } \\
\text { cells ) }\end{array}$ & Inhibited E. coli $\mathrm{O} 157: \mathrm{H} 7$ adhesion to cells and reduced Stx cytotoxicity & Di al., 2017 [190] \\
\hline & \multirow{3}{*}{ probiotics } & $\begin{array}{l}\text { In vitro }(\text { E.coli } \mathrm{O} 104: \mathrm{H} 4 \\
\quad \text { and } \mathrm{O} 157: \mathrm{H} 7)\end{array}$ & Inhibited STEC growth and Stx espresion & Mohsin et al.,2015 [193] \\
\hline & & $\begin{array}{l}\text { In vitro }(\text { E.coli } \mathrm{O} 104: \mathrm{H} 4 \\
\quad \text { and } \mathrm{O} 157: \mathrm{H} 7)\end{array}$ & Reduced STEC growth and inhibited Stx release & Rund 2013 [194] \\
\hline & & $\begin{array}{l}\text { In vitro (several STEC } \\
\text { strains) }\end{array}$ & Reduced STEC growth and inhibited Stx release & Reissbrodt et al., 2009 [195] \\
\hline Stem cells & Muse cells & In vivo (mice model) & $\begin{array}{l}\text { Protected mice chalenged with STEC and prevented neuronal damage } \\
\qquad \text { from Stx }\end{array}$ & Ozuru 2019 [198] \\
\hline \multirow{2}{*}{$\begin{array}{l}\text { Proteasome } \\
\text { inhibitor }\end{array}$} & \multirow[t]{2}{*}{ Bortezomib } & $\begin{array}{l}\text { In vitro (THP1 and U937 } \\
\text { cells) }\end{array}$ & Protected cells against Stx & \multirow[t]{2}{*}{ Hattori et al., 2015 [201] } \\
\hline & & In vivo (mice) & Protected mice challenged with Stx & \\
\hline $\begin{array}{c}\text { Inhibitor of Gb3 } \\
\text { synthesis }\end{array}$ & C-9 & In vivo (rat model) & Protected mice challenged with Stx & Silberstein et al., 2011 [202] \\
\hline $\begin{array}{l}\text { Immunoglobulin } \\
\text { G depletion }\end{array}$ & $\begin{array}{l}\text { Immunoglobulin } \mathrm{G} \\
\text { depletion }\end{array}$ & Case report & Improved in neurological and renal function & Flam et al., 2016 [203] \\
\hline Lipids & Lysophospholipids & In vitro (HEp-2 cells) & Inhibited the binding of Stx to $\mathrm{Gb} 3$ and its toxicity & Aite et al., 2016 [205] \\
\hline \multirow{4}{*}{$\begin{array}{c}\text { Retrograde } \\
\text { transport inhibi- } \\
\text { tor }\end{array}$} & \multirow{4}{*}{$\begin{array}{l}\text { Retro-1, Retro-2 \& } \\
\text { Retro-2 }^{\text {cycl }}\end{array}$} & In vitro (He La cells) & Retro- 1 and Retro-2 protected the cells against Stx & Stechmann et al., 2010 [206] \\
\hline & & In vivo (murine model) & Retro- $2^{\text {cycl }}$ protected mice chalanged with STEC O104:H4 & Secher et al., 2015 [208] \\
\hline & & In vitro (He La cells) & Retro-1 protected the cells against Stx & Abdelkafi et al., 2015 [207] \\
\hline & & In vivo (murine model) & Retro-2 protected mice chalanged with STEC O104:H4 & Gupta et al., 2017 [209] \\
\hline
\end{tabular}

(Table 1) contd.... 


\begin{tabular}{|c|c|c|c|c|}
\hline Drug Class & Drug & Type of Study & Effect & Refs. \\
\hline & \multirow{2}{*}{ Tamoxifen } & In vitro (He La cells) & Inhibited the trafficking and toxicity of Stx & \multirow{2}{*}{ Selyunin et al., 2019 [213] } \\
\hline & & In vivo (mice) & protected mice from a lethal dose of Stx & \\
\hline \multirow{4}{*}{ Metals } & \multirow{2}{*}{ Bismuth } & In vitro $($ E. coli $\mathrm{O} 157: \mathrm{H} 7$ \& $\mathrm{O} 104: \mathrm{H} 21)$ & Reduced the bacterial growth & Subils et al., 2014 [215] \\
\hline & & In vitro $($ E. coli $\mathrm{O} 157: \mathrm{H} 7)$ & Reduced the bacterial growth an production of Stx & Pitz et al., 2015 [214] \\
\hline & Zinc & In vitro ( $\mathrm{T} 84$ cells) & $\begin{array}{l}\text { Prevented the translocation of Stx into cel monolayers and } \\
\text { inhibited SOS system expression }\end{array}$ & Crane et al., 2014 [216] \\
\hline & Manganese & In vitro (He La cells) & Protected cells against Stx & Tewari et al., 2014 [217] \\
\hline
\end{tabular}

seems to be currently available to treat STEC-derived encephalopathy. In the last few years, several drugs have been experimentally employed to establish the pathogenesis of, to prevent or to treat CNS injury by STEC, with strategies relying on drug capability to inhibit either toxin entry into the cerebral parenchyma or its deleterious action once inside the CNS. Therefore, the therapeutic strategies that we postulate and describe in this review and which have been or may be used are: 1) inhibition of Stx production and release by STEC, 2) inhibition of Stx bloodstream transport, 3) inhibition of Stx entry into the CNS parenchyma, 4) blockade of deleterious Stx action in neural cells and 5) inhibition of immune system activation and CNS inflammation (Figs 2 and 3). Table 1 describes a quick description of the drugs analyzed in this review.

\subsection{Antibiotics used to Reduce STEC Encephalopathies}

\subsubsection{Polymyxin}

Antibiotic administration is not recommended in the prodromal intestinal phase of human STEC infections, as it induces the phage lysogenic cycle with the consequent increase in expression and release of Stx2 [17]. However, strong evidence suggests that the antibiotic polymyxin B blocks the interaction of Stx with human neutrophils and impairs their capability to respond to Stx, inhibiting the release of chemokines and pro-inflammatory cytokines such as CXCL8, TNF- $\alpha$ and IL-1B [79]. This blockade is most likely to take place through the interaction of polymyxin B with the A chain of Stx, responsible for binding with human neutrophil TLR4 [50, 54, 79-84]). Polymyxin B appears to exert the same protective effect against LPS [85], inhibiting its interaction with TLR4 present in monocytes and platelets and preventing the activation of these cells and the upregulation of $\mathrm{Gb} 3$ produced by pro-inflammatory cytokines, as discussed above. In addition to polymyxin $\mathrm{B}$, in vitro studies have shown that polymyxin $\mathrm{E}$ (colistin) is also efficient in inhibiting bacterial growth and Stx production by E. coli O157:H7 [86].

Polymyxin is a class of polypeptide antibiotics developed in the 1940s, which consists of amphipathic lipopeptide molecules derived from the fermentation products of bacteria Paenibacillus polymyxa. Both polymyxin B and colistin are bactericidal antibiotics whose mode of action remains controversial [79, 86-89]. It was suggested that they may act as an amphipathic detergent producing pore-like aggregates, which culminates in bacterial death, as well as the inhibition of cytokine release and LPS neutralizing effects $[88,89]$. As they do not cause damage in bacterial DNA, the bacterial SOS response (response to DNA damage which promotes the transcription of Stx genes carried by the bacteriophage genome) is not elicited, and Stx genes are therefore not expressed before cell death $[79,86]$.

However, caution is necessary for the study of Stx inhibition by polymyxin B. As the antibiotic blocks the interaction between StxA and TLR4, it would be pointless to study it in a murine model, since murine PMN expresses $\mathrm{Gb} 3$ as well as TLR4 [82], in contrast with human PMN, which only expresses TLR4 [90]. In these conditions, StxB will be preferentially bound to $\mathrm{Gb} 3$ [82]. As a consequence, other animal models should be employed to establish the efficacy of polymyxin B and its derivatives to block the Stx effect [79]. Two major adverse effects in polymyxin treatment are nephrotoxicity and neuromuscular joint blockade. These effects, however, could be bypassed through oral administration, as polymyxin is only slightly absorbed and mostly eliminated by the gastrointestinal tract [86]. In sum, more research is needed on polymyxin beneficial effects.

\subsubsection{Fosfomycin}

Fosfomycin is a bactericidal broad-spectrum antibiotic first isolated in 1969 from cultures of Streptomyces spp. This antibiotic has a unique mechanism of action in which it reduces penicillin-binding proteins and inhibits the first step in peptidoglycan biosynthesis, leading to bacterial cell lysis and death. It reaches the bacterial cytoplasm using both the hexose monophosphate and the L-a-glycerophosphate transport system [91].

A study of 118 children with STEC infection between 1997 and 2013 [92] determined that the use of fosfomycin within the first 5 days of STEC infection restricted the development of HUS. Furthermore, another study of 292 children with E. coli $\mathrm{O} 157$ infection [93] reported that fosfomycin should be administered in a rather smaller time window, during the first 2 days of illness, in order to reduce the risk of HUS. However, a case report in 2017 [94] described the evolution of a 20 -year-old woman whose digestive symptoms improved after fosfomycin treatment four days from the beginning of gastroenteritis with EHEC O26, who was then diagnosed with HUS a day after treatment. This patient be- 
gan supportive care treatment with improvements in symptoms but developed acute encephalopathy five days later. Subsequent treatment with $1 \mathrm{~g}$ /day methylprednisolone pulse therapy (mPSL) for three days later proved to be beneficial, as neurologic symptoms, hemolytic anemia, low platelet count and renal dysfunction all improved. The patient was finally discharged without any sequelae 23 days later.

\subsubsection{Azithromycin}

Azithromycin, a broad-spectrum macrolide antibiotic with bacteriostatic activity against many Gram-positive and Gram-negative bacteria, has also been reported as a possible therapeutic strategy to be employed due to its potential beneficial effect in the prevention of HUS and/or encephalopathy derived from infection with STEC [95]. In contrast to newer fluoroquinolones [96, 97], azithromycin has been able to inhibit the in vitro growth of STEC strains without the production of Stx. Another characteristic of this class of antibiotics is its immunomodulatory activities, such as the inhibition of neutrophil chemotaxis and oxidative burst and the release of pro-inflammatory cytokines from monocytes [98101]. Azithromycin can also inhibit the Stx-induced production of inflammatory cytokines TNF-, IL-1 and IL-6 and prevent death in mice exposed to Stx or STEC [95].

\subsection{Anti-inflammatory Drugs}

\subsubsection{Corticosteroid}

Given the importance of the pro-inflammatory response produced by Stx and LPS, several authors have reported the use of anti-inflammatory steroids in clinical cases and in animal models of encephalopathy produced by Stx. Clinically, corticosteroid therapy has been used since the early 1960 s [102, 103], although controversial results in therapy success have also been reported [104].

\subsubsection{Betamethasone}

Betamethasone is a synthetic, long-acting corticosteroid with high potency glucocorticoid (25 times more potent than cortisol) but minimal mineralocorticoid activity. Betamethasone pulse therapy has been found to reduce the mortality rate and improve the survival period of Stx2-toxemic rabbits with doses 8 times higher than those used in humans [105].

\subsubsection{Methylprednisolone}

Still, currently in use, methylprednisolone therapy has been extensively reported to exert neuroprotective effects and reverse CNS damage without sequelae [59, 60, 94, 106$110]$.

\subsubsection{Dexamethasone}

As corticosteroid is used in animal models, dexamethasone has proven to be a good neuroprotective candidate and is one of the most common corticosteroids used in medicine. It has a biological response thirty times more potent than endogenous cortisol and, in contrast to the latter, has virtually no mineralocorticoid effects [111]. Many of the antiinflammatory effects of glucocorticoids are mediated by their inhibitory action on inflammatory cells, the generation of arachidonic acid-derived pro-inflammatory mediators and cytokine production [112]. Furthermore, dexamethasone blocks platelet aggregation [113] and increases the expression of occludin, a protein present in $\mathrm{BBB}$ endothelial tight junctions [111], which makes the BBB less permeable.

Dexamethasone has been shown to increase the survival of mice challenged with two lethal doses of Stx2 and, consequently, to protect neuronal populations, reduce astrocyte/microglial reactivity, myelin sheath damage and $\mathrm{BBB}$ permeability, and restore endothelial VEGF basal expression [56, 105, 114-116]. Overall, treatment with dexamethasone results in improved motor behavior.

\subsubsection{Etanercept}

This anti-inflammatory drug is a TNF- $\alpha$ inhibitor which blocks its interaction with cell surface TNF- $\alpha$ receptors. Etanercept is a dimeric fusion protein consisting of the extracellular ligand-binding portion of the human TNF- $\alpha$ receptor linked to the Fc portion of human IgG1 and is produced by recombinant DNA technology in a Chinese hamster ovary mammalian cell expression system [117, 118]. Etanercept has a binding affinity to TNF- $\alpha$, which is up to 1000 -fold higher than that of the natural TNF- $\alpha$ receptors [119]. Etanercept has been reported to protect animals against a lethal dose of Stx2 through a reduction in neuronal Stx2 uptake [116]. As etanercept promotes the clearance of TNF- $\alpha$, it may be thought to prevent Gb3 neuronal upregulation induced by TNF- $\alpha$ and other pro-inflammatory cytokines $[58,116]$.

However, the anti-inflammatory efficacy of etanercept is reduced in prolonged administration. Although the underlying mechanisms have not been described yet, a possible explanation lies in the development of anti-etanercept antibodies. This effect may be prevented through combined treatment with corticosteroids, as recommended in the case of psoriatic arthritis [120].

\subsection{Vasoactive Drugs}

\subsubsection{Angiotensin 1-7}

A recent article reported that angiotensin 1-7 succeeded in preventing neural damage following the intra-cerebroventricular treatment of Stx2 [121]. For many years since the development of the first oral inhibitor of the angiotensinconverting enzyme (ACE), responsible for the conversion of angiotensin I to angiotensin II, the renin-angiotensin system (RAS) has been the primary therapeutic target for the treatment of hypertension and related diseases. An alternative pathway for angiotensin metabolism and signaling is related to the action of the angiotensin-converting enzyme 2 (ACE2), which transforms angiotensin II into angiotensin 17 [122]. The latter exerts its effect through a unique Gprotein-coupled receptor known as MAS. The activation of MAS produces anti-inflammatory, antioxidant, vasodilatory and angiogenic effects, which have proven beneficial in many animal models of CNS damage by stroke [123-127] and inflammation-related disease models including arthritis, hypertensive kidney disease, atherosclerosis, asthma and acute respiratory distress syndrome [128-132]. In this model, Stx 2 produced neurodegeneration, demyelination and astro- 
cyte damage, accompanied by edema, which angiotensin 1-7 was able to prevent in neurons and oligodendrocytes, but partially only in astrocytes. On the other hand, angiotensin 17 failed to prevent in vitro oligodendrocyte damage produced by Stx2, which suggests that its protective effects may be mediated by its neuronal receptor $[133,134]$, with a key role of cellular interaction.

\subsubsection{Anisodamine}

Another vasoactive drug employed in Stx-producing disease models, anisodamine (6-[s]hydroxyhyoscyamine), is an atropine derivative from Scopaliatangutica [135]. This drug is a non-specific cholinergic antagonist with respect to M1 and M2 receptors and appears to be less potent and toxic than atropine [136]. Anisodamine has vasodilating activity due to its relatively weak $\alpha 1$ adrenergic antagonism, and experimental evidence suggests antioxidant and superoxide scavenging activity as well [135]. Moreover, anisodamine presents antithrombotic activity, as it inhibits thromboxane synthesis [137]. Broad therapeutic uses have been proposed, including disorders related to the autonomic nervous system, migraine, gastric ulcers, gastrointestinal colic, acute glomerulonephritis, eclampsia, respiratory diseases, rheumatoid arthritis, snake bites and radiation damage, among others [135].

In Stx1-producing disease models, anisodamine has been able to increase the survival of Stx1-treated mice, a beneficial effect which may be due to the inhibition of proinflammatory cytokine TNF- $\alpha$, IL- $1 \beta$ and IL- 8 synthesis by human peripheral blood monocytes via a PGE2-dependent mechanism. Furthermore, anisodamine may also produce a beneficial effect by improving microvascular circulation [138].

\subsection{Antibodies}

\subsubsection{Eculizumab}

Several authors have reported hypocomplementemia in approximately one-third of children with HUS [139-146]. This clinical sign is strongly associated with severe episodes of HUS-derived encephalopathy and with poor prognosis $[140,147]$. It is not clear why Stx promotes the complement system activation only in a fraction of affected children; however, children with hypocomplementemia are known to be significantly younger than those with normal blood complement levels [140].

Circulating Stx directly activates the complement system and also binds and neutralizes factor $\mathrm{H}$, a soluble complement regulator essential for controlling the alternative pathway [148]. Therefore, treatment with a complement inhibitor may be beneficial to prevent STEC-derived encephalopathies and, consequently, death from this disease.

Accordingly, many reported cases of STEC-derived encephalopathies describe the therapeutic use of the C5 complement molecule inhibitor eculizumab [68, 140, 141, 148152]. Eculizumab is a humanized chimeric monoclonal antibody comprising a human constant region and a murine complementarity determining region grafted onto human framework light and heavy chain variable regions. It is designed to bind one or two C5 molecules to inhibit their acti- vation and thus block terminal complement activation [148, $153,154]$.

Although the pathogenic mechanism in encephalopathy produced by Stx is not yet fully understood, evidence suggests direct damage of neural cells by the toxin [155], indirect cerebral damage by inflammation $[56,115,116]$ and cerebral thrombotic microangiopathy [156]. Complementmediated neurological impairment in STEC infections has been described by many authors and early treatment with eculizumab has proven more efficient than plasmapheresis in improving neurological status [69]. In contrast, late eculizumab treatment following unsuccessful treatment with plasmapheresis has shown no benefits [157].

\subsubsection{Passive and Active Immune Therapy}

A logical strategy to protect the CNS against the detrimental action of Stx is the employment of passive immune therapy with anti-Stx antibodies or active immune therapy to neutralize the toxin long before brain damage occurs. In this context, pre-clinical studies using chimeric murine-human monoclonal antibodies have been developed since the late 1980s [158] and are, until now, the most effective treatment so far. In vitro and in vivo models [159-164] using monoclonal antibodies have demonstrated success in neutralizing the toxic and lethal effects of Stx, respectively. Recently, healthy adult volunteers have received treatment with antiStx antibodies corresponding to phase 1 safety and pharmacokinetic trials [159, 165-167]. These studies showed that all these antibodies were well tolerated, which makes them good candidates to be employed in the next phase of clinical trials.

Neutralizing antibodies targeting StxB to prevent the binding of Stx to Gb3 constitute the theoretical basis of active immunization against Stx. However, as it turns out to be StxB a poor immunogen researchers developed a vaccine with an engineered chimeric molecule consisting of StxB bound to Brucellaspp's enzyme lumazine synthase [168, 169]. This new immunogen molecule has demonstrated a strong capacity to induce long-lasting humoral immune response with a high neutralizing capacity for Stx 2 in a murine model of systemic delivery of Stx 2 or even oral challenge of EHEC. This novel immunogen represents a promising candidate for vaccine or antibody development with preventive or therapeutic ends. Furthermore, female mice immunized before mating with the chimeric Brucella lumazine synthase-StxB developed a strong humoral response, while their offspring acquired a very similar titer of the antibody through transplacental and breastfeeding. Moreover, pups were totally protected against systemic injection of a lethal dose of Stx up to 3 months postpartum and against EHEC infection at weaning [168].

\subsection{Polyphenols}

Polyphenols are phytochemicals primarily found in fruits, vegetables, cereals and beverages, which are generally involved in defense against ultraviolet radiation or aggression by pathogens. More than $3 \mathrm{mg}$ of polyphenols can be found per gram in fresh weight fruits like grapes, apples, pears, cherries and berries [170]. Epidemiological and associated 
meta-analysis studies strongly suggest that long-term consumption of diets rich in plant polyphenols offers protection against cancer, cardiovascular disease, diabetes, osteoporosis, neurodegenerative diseases and infections [171-173]. The beneficial action of polyphenols may be due to the presence of an antioxidant phenolic group which can accept an electron to form a relatively stable phenosyl radical, thus increasing plasma antioxidant capacity [174]. Non-identified polyphenols from grape seed and pomace extracts were reported as molecules with potential inhibitory power of the toxic effect of Stx, as observed in Vero cells [175].

\subsubsection{Baicalin}

Baicalin (5, 6-dihydroxy-7-O-glucuronide flavone) is a polyphenol from Scutellaria baicalens employed in traditional Chinese medicine for the treatment of lung and liver diseases, diarrhea, dysentery, high blood pressure, bleeding, insomnia and inflammation [176]. Baicalin presents various pharmacological properties, including anti-oxidative, antiviral, anti-inflammatory, anti-HIV and antineoplastic activity [177].

Baicalin has been able to protect HeLa [178, 179] and Vero cells [180] against Stx2, either after pre-treatment with Baicalin or even upon pre-incubation with Stx2. In turn, mice were challenged either with a lethal dose of Stx [178] or a lethal charge of E. coli O157:H7 [179], both to be later treated with oral baicalin, showing $70 \%$ and $80 \%$ protection, respectively. Furthermore, baicalin reduced the systemic production of IL-1, IL-4, IL-6, TNF- $\alpha$ and INF- $\gamma$ in both models. Although baicalin showed no effects on the production or secretion of Stx, docking models revealed that the inhibitory activity of baicalin against Stx might be due to the formation of a binding structure inside the pocket of the StxB pentamers [180].

\subsubsection{Catechins: Gallocatechin Gallate (GCg) and Epigal- locatechin Gallate (EGCg)}

Catechins are natural polyphenolic compounds found mainly in tea leaf (Camellia sinensis) and other vegetables [181-184]. These compounds have many valuable properties such as anti-bacterial, anti-viral, anti-oxidative and antitumor activity [185-188].

From six different catechin derivatives contained in green tea extracts, $\mathrm{GCg}$ and $\mathrm{EGCg}$ were found to inhibit bacterial growth. Furthermore, $\mathrm{GCg}$ and $\mathrm{EGCg}$ that suppressed the release of Stx from STEC failed to block the production of Stx, as they act by inhibiting the leakage of molecules from periplasm [181].

\subsection{Pharmabiotics}

Pharmabiotic is a general term denoting the therapeutic use of commensal microbiota, which includes the use of prebiotics and live probiotic microorganisms [189].

\subsubsection{Prebiotics}

Prebiotics are selectively fermented non-digestible food ingredients which induce specific changes in the composition and/or activity of the gastrointestinal microbiota and thus offer benefits to host health [190]. Typical prebiotics, such as fructo- or galacto-oligosaccharides or lactulose, are selectively fermented and thus increased by beneficial bacteria in the colon [191]. Pectic oligosaccharides are derived from pectin, a polysaccharide found in high amounts in citrus fruits, which presents a partially methylesterified homogalacturonan backbone [192]. When pectin is consumed, it reaches the colon and becomes fermented by microbiota, hence yielding oligosaccharides and smaller metabolites [192]. In vitro studies have demonstrated the protective role of pectin and pectic-oligosaccharides against Stx lethality in human colonic cell line HT29 [193]. Furthermore, pecticoligosaccharides showed anti-adhesive properties, inhibiting the binding of E. coli O157:H7 to human HT29 cells [194].

\subsubsection{Probiotics}

Probiotics are live non-pathogenic microorganisms (Saccharomyces boulardii yeast or lactic acid bacteria, such as Lactobacillus and Bifidobacterium species), which, when administered in adequate amounts, provide health benefits to the host $[189,195,196]$. Probiotics exert their beneficial effects through various mechanisms, including lowering intestinal $\mathrm{pH}$, decreasing colonization and invasion by pathogenic organisms and beneficially modifying the host immune response. Probiotics have been commonly targeted at illnesses associated with the gastrointestinal tract, mainly due to their ability to restore gut microbiota [196].

Escherichia coli Nissle $1917(\mathrm{EcN})$ is a probiotic strain which has displayed an inhibitory effect on toxin growth and gene expression, Stx release and cytotoxicity in STEC serotypes O104:H4 and O157:H7 [197]. Furthermore, adhesion of STEC strains to Caco-2 cells and mucin-producing LS $174 \mathrm{~T}$ cells has been significantly reduced upon co-culture with $\mathrm{EcN}$ [198]. On the other hand, routine quality control testing of STEC rendered Stx detection in only about $39 \%$ of all samples tested positive for STEC strains [199]. A particular E. coli strain isolated from stool samples of STECinfected Stx-negative patients, the non-probiotic E. coli 1307 proved to possess probiotic like-properties similar to those of $\mathrm{EcN}$, as it reduced bacterial growth and inhibited Stx release when co-cultured with STEC strains [199].

\subsection{Stem Cells}

\subsubsection{Multilineage-differentiating Stress-enduring (Muse) Cells}

Muse cells are endogenous non-tumorigenic stem cells with the ability to sense, migrate to and populate the site of tissue damage, therefore replenishing it with new functional cells by spontaneous differentiation and inducing functional and structural repair. They are also stress-tolerant cells which perform anti-fibrotic, anti-inflammatory and anti-apoptotic functions. Due to their immunomodulatory effect, allograft and xenograft Muse cells may escape from host immunologic attack and thus efficiently settle in the damaged site. Muse cells can be intravenously administrated to patients after collection and expansion from tissue sources [200]. Moreover, Muse cells have been applied to clinical trials for acute myocardial infarction, stroke and spinal cord injury by intravenous injection of donor-derived cells without HLAmatching or immunosuppressant treatment [201]. Muse cells 
have also shown a beneficial effect on STEC-associated acute encephalopathy, as they protected $100 \%$ of mice against lethal treatment with STEC O111. Immunohistochemical analysis showed a decrease in astrocyte reactivity and caspase- 3 inhibition, accompanied by a neuron-like morphology of the human Muse cells detected through an anti-Cox 4 antibody in the mouse brain parenchyma. These findings suggest that Muse cells produced a beneficial effect by crossing the BBB. Furthermore, a single injection of as few as $5 \times 10^{4}$ Muse cells $48 \mathrm{~h}$ after $\mathrm{O} 111$ infection proved to prevent neuronal damage by Stx [202].

Among the compounds produced by Muse cells, the granulocyte-colony-stimulating factor (G-CSF) has been unequivocally identified as a neuroprotectant, as the suppression of G-CSF by iARN reduced the beneficial effects of these cells. G-CSF has also been observed to maintain aquaporin type 4 integrity and induce vascular endothelial growth factor, which improved neurologic functions by reducing brain edema, BBB permeability, neuronal death and apoptosis [203]. G-CSF also stimulated the proliferation of neuronal/glial progenitor cells, producing an improvement in neurocognitive function, and succeeded in repairing cerebral white matter damage by irradiation [204].

\subsection{Proteasome Inhibitor}

It has been reported that the clinically approved proteasome inhibitor bortezomib manages to inhibit Stx1-induced apoptosis in vitro through the mitochondrial pathway of caspases 9-3. It was observed in vitro that the levels of apoptosis inhibitory proteins decreased due to proteasomal degradation, followed by caspase activation and apoptosis progression. In this context, proteasome inhibitors succeeded in preventing the Stx-induced reduction in anti-apoptotic proteins Apollon, XIAP, c-IAP1, FLIP and Mcl-1 and, consequently, the progression of apoptosis. Furthermore, in vivo bortezomib administration prolonged the survival of mice intoxicated with Stx. Therefore, even if high $2 \mathrm{mg} / \mathrm{kg}$ doses of bortezomib in the present study proved to be toxic and its potential clinical use should be handled with caution, inhibition of the proteasome may be beneficial in the treatment of patients affected by Stx intoxication [205].

\subsection{Gb3 Synthesis Inhibitor}

Another strategy to prevent the deleterious action of Stx is to reduce the expression of the Stx Gb3-receptor using C-9 [(1R, 2R)-nonanoic acid [2-(2', 3'-dihydro-benzo (1-4) dioxin-6'-yl)-2-hydroxy-1-pyrrolidin-1-ylmethyl-ethyl]-amideL-tartaric acid salt], a competitive inhibitor of the glucosylceramide synthase, responsible for rate-limiting the first step in the biosynthesis of Gb3 and globosides in general [206]. The use of this drug, administered 2 days before Stx 2 systemic delivery, managed to reduce the mortality rate in rats by $50 \%$. However, the fact that C-9 does not cross the BBB may explain its failure in attaining total survival. Alternatively, as C-9 inhibits the expression of the whole globoside series and knowledge currently available on Gb3 and other globosides biological functions is still limited, this drug may be thought to interfere with physiological functions, which calls for more preclinical studies with this drug in the treatment of the systemic effects of STEC infection.

\subsection{Immunoglobulin G (IgG) Depletion}

Another type of treatment employs IgG depletion by immunoadsorption, which has succeeded in rapidly improving neurological and renal functions. However, as the specificity of the antibody toward CNS antigens could not be identified, authors hypothesize that the effect of IgG depletion could be due to the elimination of autoantibodies or harmful immune complexes with Stx. Therefore, it has been postulated that late neurological involvement in STEC-HUS may be mediated by immune factors [207].

\subsection{Lysophospholipids}

In vitro studies have shown that the conformation quality of the lipid bilayer of the plasma membrane could determine the binding of Stx to the Gb3 receptor [208]. In this regard, incubation of lysophospholipids such as lysophosphatidylinositol, which has a large polar head with an extensive and saturated fatty acyl chain, has a conical structure that inhibits the binding of Stx or Stx2 to Gb3 and, hence, toxicity in HEp-2 cells. In contrast, this does not happen with lysophospholipids having a small polar head and non-saturated shorter fatty acyl chains, which give a cylindrical structure. Therefore, lysophospholipids such as lysophosphatidylinositol change the physicochemical properties of the plasma membrane, which leads to alterations in the conformation and/or distribution of the Gb3 receptor [209].

\subsection{Retrograde Transport Inhibitor}

\subsubsection{Retro-1, Retro-2 \& Retro- $2^{\text {cycl }}$}

Another strategy to neutralize the cytotoxic effect of Stx is inhibiting the retrograde transit of this toxin inside the cells. Three components have been found to specifically block the early endosome-to-trans Golgi network toxin transport step without affecting endogenous retrograde cargo proteins, other intracellular trafficking pathways, or, more generally, organelle integrity. It was observed that Retro-1 and Retro- 2 protected HeLa cells from the lethal effect of Stx [210, 211]. Moreover, Retro-2 and Retro- $2^{\text {cycl }}$ protected mice against a challenge with a lethal oral charge of STEC O104:H4 [212, 213].

\subsubsection{Tamoxifen (TAM)}

TAM is an antiestrogenic drug widely used for the treatment of estrogen receptor- $\alpha$-positive breast cancer [214]. TAM inhibits the trafficking and toxicity of Stx in HeLa cells, which lack estrogen receptors but are sensitive to Stx $[215,216]$. This protective effect is independent of estrogen receptors but rather more related to TAM weak base properties, which increase endolysosomal $\mathrm{pH}$. This property results from the chemical structure of TAM, characterized by a tertiary amine group. As a result, TAM has been shown to protect mice from a lethal dose of Stx [217].

\subsection{Divalent and Trivalent Metals}

The antibacterial effects of certain trivalent/divalent metals have been demonstrated in recent years. Bismuth salts or colloidal bismuth hydroxide gel have been observed to reduce the bacterial growth of $E$. coli $\mathrm{O} 157: \mathrm{H} 7$ and E coli $\mathrm{O} 104: \mathrm{H} 21$ in vitro within 48 hours, as evidenced by the degradation of 
the cell wall, inhibition of plasma membrane function and impediment of protein and ATP synthesis [218, 219].

It has been reported that zinc offered protection against STEC infection by reducing the expression of the SOS system in the presence of hydrogen peroxide, xanthine oxidase or antibiotic ciprofloxacin in the gastrointestinal tract. Zinc also had protective effects on enterocytes, by restoring the impermeability of tight junctions, on the one hand, and preventing the translocation of Stx into monolayers, on the other [220].

Finally, manganese has been used to degrade cycling transmembrane protein GPP130, which Stx uses as an intracellular traffic receptor. The role of manganese lies in its union with GPP130, which blocks toxin movement to the Golgi to be led to lysosomes, where it is degraded and purified from infected cells. Manganese treatment could then be accessible, given its low cost and availability [221].

\section{CONCLUSION}

At present, there is no consensus high-efficiency treatment for STEC infections and only supportive treatment is employed for STEC-infected patients. Once the patient is diagnosed, hospitalization and volume expansion therapy are required to monitor the progression of the disease and maintain the level of hydration, respectively [159]. In this review, we intended to provide a wide range of therapeutic strategies aimed, on the one hand, to eliminate the bacteria from the gut without producing and releasing Stx and, on the other hand, to block the action and the effect of Stx systemically and locally in the CNS.

An important question to be solved is when to start an effective treatment. There are only a few clinical studies reporting a therapeutic time window for effective pharmacological treatment (fosfomycin within the first 2 to 5 days of STEC infection $[92,93])$. Furthermore, the administration of Gb3 analogs orally provided to positively diagnosed diarrhea-HUS-patients has been tested as a treatment specifically aimed to neutralize the toxin at the intestinal level [222]. The study showed that patients who received Gb3 analogs had similar clinical evolution to those who received the placebo. This evidence suggests that the time window for therapeutic approaches aiming at preventing toxin release by bacteria and/or toxin arrival at the bloodstream is shorter than that required for drugs of systemic action. Therefore, fast diagnosis of STEC infection, as well as the establishment of early biomarkers of CNS damage, may be crucial to a rapid pharmacological approach. Early treatment by early diagnosis may lead to a better prognosis and a reduction in death or sequelae.

\section{CONSENT FOR PUBLICATION}

Not applicable.

\section{FUNDING}

This work was supported by Agencia Nacional de Promoción Científica y Tecnológica (ANPCyT) (PICT2016-1175) and Universidad de Buenos Aires (UBACyT) (20020160100135BA), Argentina.

\section{CONFLICT OF INTEREST}

The authors declare no conflict of interest, financial or otherwise.

\section{ACKNOWLEDGEMENTS}

We were grateful to María Marta Rancez for her special dedication and technical assistance.

\section{REFERENCES}

[1] Konowalchuk, J.; Dickie, N.; Stavric, S.; Speirs, J.I. Properties of an Escherichia coli cytotoxin. Infect. Immun., 1978, 20(2), 575-577. http://dx.doi.org/10.1128/IAI.20.2.575-577.1978 PMID: 208977

[2] Donnenberg, M.S. Escherichia coli: Pathotypes and Principles of Pathogenesis., 2013, $2^{\text {nd }}$ Edition.

[3] Levine, M.M. Escherichia coli that cause diarrhea: enterotoxigenic, enteropathogenic, enteroinvasive, enterohemorrhagic, and enteroadherent. J. Infect. Dis., 1987, 155(3), 377-389.

http://dx.doi.org/10.1093/infdis/155.3.377 PMID: 3543152

[4] Zuverink, M.; Barbieri, J.T. Protein toxins that utilize gangliosides as host receptors. Prog. Mol. Biol. Transl. Sci., 2018, 156, 325-354. http://dx.doi.org/10.1016/bs.pmbts.2017.11.010 PMID: 29747819

[5] Chaudhuri, K.; Chatterjee, S.N. Cholera Toxins., 2009, Springer. http://dx.doi.org/10.1007/978-3-540-88452-1

[6] Launders, N.; Byrne, L.; Jenkins, C.; Harker, K.; Charlett, A.; Adak, G.K. Disease severity of Shiga toxin-producing E. coli O157 and factors influencing the development of typical haemolytic uraemic syndrome: a retrospective cohort study, 2009-2012. BMJ Open, 2016, 6(1), e009933.

http://dx.doi.org/10.1136/bmjopen-2015-009933 PMID: 26826153

[7] Fakhouri, F.; Zuber, J.; Frémeaux-Bacchi, V.; Loirat, C. Haemolytic uraemic syndrome. Lancet, 2017, 390(10095), 681-696. http://dx.doi.org/10.1016/S0140-6736(17)30062-4 PMID: 28242109

[8] Picard, C.; Burtey, S.; Bornet, C.; Curti, C.; Montana, M.; Vanelle, P. Pathophysiology and treatment of typical and atypical hemolytic uremic syndrome. Pathol. Biol. (Paris), 2015, 63(3), 136-143. http://dx.doi.org/10.1016/j.patbio.2015.03.001 PMID: 25845294

[9] Noris, M.; Remuzzi, G. Hemolytic uremic syndrome. J. Am. Soc. Nephrol., 2005, 16(4), 1035-1050. http://dx.doi.org/10.1681/ASN.2004100861 PMID: 15728781

[10] Karmali, M.A.; Steele, B.T.; Petric, M.; Lim, C. Sporadic cases of haemolytic-uraemic syndrome associated with faecal cytotoxin and cytotoxin-producing Escherichia coli in stools. Lancet, 1983, l(8325), 619-620.

http://dx.doi.org/10.1016/S0140-6736(83)91795-6 PMID: 6131302

[11] Karmali, M.A.; Petric, M.; Lim, C.; Fleming, P.C.; Arbus, G.S.; Lior, H. The association between idiopathic hemolytic uremic syndrome and infection by verotoxin-producing Escherichia coli. J. Infect. Dis., 1985, 151(5), 775-782.

http://dx.doi.org/10.1093/infdis/151.5.775 PMID: 3886804

[12] Torres, A.G.; Amaral, M.M.; Bentancor, L.; Galli, L.; Goldstein, J.; Krüger, A.; Rojas-Lopez, M. Recent advances in shiga toxinproducing Escherichia coli Research in Latin America. Microorganisms, 2018, 6(4), E100.

http://dx.doi.org/10.3390/microorganisms6040100 PMID: 30274180

[13] Alconcher, L.F.; Coccia, P.A.; Suarez, A.D.C.; Monteverde, M.L.; Perez Y Gutiérrez, M.G.; Carlopio, P.M.; Missoni, M.L.; Balestracci, A.; Principi, I.; Ramírez, F.B.; Estrella, P.; Micelli, S.; Leroy, D.C.; Quijada, N.E.; Seminara, C.; Giordano, M.I.; Hidalgo Solís, S.B.; Saurit, M.; Caminitti, A.; Arias, A.; Rivas, M.; Risso, P.; Liern, M. Hyponatremia: a new predictor of mortality in patients with Shiga toxin-producing Escherichia coli hemolytic uremic syndrome. Pediatr. Nephrol., 2018, 33(10), 1791-1798. http://dx.doi.org/10.1007/s00467-018-3991-6 PMID: 29961127

[14] Karch, H.; Schmidt, H.; Janetzki-Mittmann, C.; Scheef, J.; Kröger, M. Shiga toxins even when different are encoded at identical positions in the genomes of related temperate bacteriophages. Mol. Gen. Genet., 1999, 262(4-5), 600-607.

http://dx.doi.org/10.1007/s004380051122 PMID: 10628842 
[15] Wagner, P.L.; Livny, J.; Neely, M.N.; Acheson, D.W.; Friedman, D.I.; Waldor, M.K. Bacteriophage control of Shiga toxin 1 production and release by Escherichia coli. Mol. Microbiol., 2002, 44(4), 957-970.

http://dx.doi.org/10.1046/j.1365-2958.2002.02950.x PMID:

\section{1}

[16] Wagner, P.L.; Waldor, M.K. Bacteriophage control of bacterial virulence. Infect. Immun., 2002, 70(8), 3985-3993. http://dx.doi.org/10.1128/IAI.70.8.3985-3993.2002 PMID:

\section{3}

[17] Freedman, S.B.; Xie, J.; Neufeld, M.S.; Hamilton, W.L.; Hartling, L.; Tarr, P.I.; Nettel-Aguirre, A.; Chuck, A.; Lee, B.; Johnson, D.; Currie, G.; Talbot, J.; Jiang, J.; Dickinson, J.; Kellner, J.; MacDonald, J.; Svenson, L.; Chui, L.; Louie, M.; Lavoie, M.; Eltorki, M.; Vanderkooi, O.; Tellier, R.; Ali, S.; Drews, S.; Graham, T.; Pang, X.L. Alberta provincial pediatric enteric infection team (appetite). shiga toxin-producing Escherichia coli Infection, antibiotics, and risk of developing hemolytic uremic syndrome: a metaanalysis. Clin. Infect. Dis., 2016, 62(10), 1251-1258.

http://dx.doi.org/10.1093/cid/ciw099 PMID: 26917812

[18] Goldwater, P.N.; Bettelheim, K.A. Treatment of enterohemorrhagic Escherichia coli (EHEC) infection and hemolytic uremic syndrome (HUS). BMC Med., 2012, 10, 12.

http://dx.doi.org/10.1186/1741-7015-10-12 PMID: 22300510

[19] Bitzan, M.; Moebius, E.; Ludwig, K.; Müller-Wiefel, D.E.; Heesemann, J.; Karch, H. High incidence of serum antibodies to Escherichia coli $\mathrm{O} 157$ lipopolysaccharide in children with hemolyticuremic syndrome. J. Pediatr., 1991, 119(3), 380-385.

http://dx.doi.org/10.1016/S0022-3476(05)82049-9 PMID: 1880650

[20] Spika, J.S.; Parsons, J.E.; Nordenberg, D.; Wells, J.G.; Gunn, R.A.; Blake, P.A. Hemolytic uremic syndrome and diarrhea associated with Escherichia coli $\mathrm{O} 157: \mathrm{H} 7$ in a day care center. J. Pediatr., 1986, 109(2), 287-291.

http://dx.doi.org/10.1016/S0022-3476(86)80386-9 PMID: 3525791

[21] Carter, A.O.; Borczyk, A.A.; Carlson, J.A.; Harvey, B.; Hockin, J.C.; Karmali, M.A.; Krishnan, C.; Korn, D.A.; Lior, H. A severe outbreak of Escherichia coli O157:H7--associated hemorrhagic colitis in a nursing home. N. Engl. J. Med., 1987, 317(24), 14961500 .

http://dx.doi.org/10.1056/NEJM198712103172403 PMID: 3317047

[22] Rowe, P.C.; Orrbine, E.; Lior, H.; Wells, G.A.; McLaine, P.N. Diarrhoea in close contacts as a risk factor for childhood haemolytic uraemic syndrome. The CPKDRC co-investigators. Epidemiol. Infect., 1993, 110(1), 9-16.

http://dx.doi.org/10.1017/S0950268800050627 PMID: 8432328

[23] Rangel, J.M.; Sparling, P.H.; Crowe, C.; Griffin, P.M.; Swerdlow, D.L. Epidemiology of Escherichia coli O157:H7 outbreaks, United States, 1982-2002. Emerg. Infect. Dis., 2005, 11(4), 603-609. http://dx.doi.org/10.3201/eid1104.040739 PMID: 15829201

[24] Steiner, T.S.; Thielman, N.M.; Gerrant, R.L. Enteric Escherichia coli Infections.Tropical Infectious Diseases: Principles, Pathogens and Practice; Geuerrant, R.L.; Walker, D.H.; Weller, P.F., Eds.; 2011, pp. 110-120.

http://dx.doi.org/10.1016/B978-0-7020-3935-5.00015-X

[25] Scheutz, F.; Teel, L.D.; Beutin, L.; Piérard, D.; Buvens, G.; Karch, H.; Mellmann, A.; Caprioli, A.; Tozzoli, R.; Morabito, S.; Strockbine, N.A.; Melton-Celsa, A.R.; Sanchez, M.; Persson, S.; O’Brien, A.D. Multicenter evaluation of a sequence-based protocol for subtyping Shiga toxins and standardizing Stx nomenclature. J. Clin. Microbiol., 2012, 50(9), 2951-2963.

http://dx.doi.org/10.1128/JCM.00860-12 PMID: 22760050

[26] Calderwood, S.B.; Auclair, F.; Donohue-Rolfe, A.; Keusch, G.T.; Mekalanos, J.J. Nucleotide sequence of the Shiga-like toxin genes of Escherichia coli. Proc. Natl. Acad. Sci. USA, 1987, 84(13), 4364-4368.

http://dx.doi.org/10.1073/pnas.84.13.4364 PMID: 3299365

[27] Tesh, V.L. Activation of cell stress response pathways by Shiga toxins. Cell. Microbiol., 2012, 14(1), 1-9. http://dx.doi.org/10.1111/j.1462-5822.2011.01684.x PMID: 21899699

[28] Griffin, P.M.; Tauxe, R.V. The epidemiology of infections caused by Escherichia coli O157:H7, other enterohemorrhagic E. coli, and the associated hemolytic uremic syndrome. Epidemiol. Rev., 1991, $13,60-98$. http://dx.doi.org/10.1093/oxfordjournals.epirev.a036079 PMID: 1765120

[29] Boerlin, P.; McEwen, S.A.; Boerlin-Petzold, F.; Wilson, J.B.; Johnson, R.P.; Gyles, C.L. Associations between virulence factors of Shiga toxin-producing Escherichia coli and disease in humans. $J$. Clin. Microbiol., 1999, 37(3), 497-503.

http://dx.doi.org/10.1128/JCM.37.3.497-503.1999 PMID: 9986802

[30] Donnenberg, M.S. Escherichia coli: virulence mechanisms of a versatile pathogen; Academic Press: San Diego, Calif., 2002.

[31] Beutin, L.; Krüger, U.; Krause, G.; Miko, A.; Martin, A.; Strauch, E. Evaluation of major types of Shiga toxin 2E-producing Escherichia coli bacteria present in food, pigs, and the environment as potential pathogens for humans. Appl. Environ. Microbiol., 2008, 74(15), 4806-4816.

http://dx.doi.org/10.1128/AEM.00623-08 PMID: 18515483

[32] Beddoe, T.; Paton, A.W.; Le Nours, J.; Rossjohn, J.; Paton, J.C. Structure, biological functions and applications of the AB5 toxins. Trends Biochem. Sci., 2010, 35(7), 411-418.

http://dx.doi.org/10.1016/j.tibs.2010.02.003 PMID: 20202851

[33] Fraser, M.E.; Fujinaga, M.; Cherney, M.M.; Melton-Celsa, A.R.; Twiddy, E.M.; O'Brien, A.D.; James, M.N. Structure of shiga toxin type 2 (Stx2) from Escherichia coli O157:H7. J. Biol. Chem., 2004, 279(26), 27511-27517.

http://dx.doi.org/10.1074/jbc.M401939200 PMID: 15075327

[34] Sandvig, K.; Dubinina, E.; Garred, O.; Prydz, K.; Kozlov, J.V.; Hansen, S.H.; Van Deurs, B. Entry of Shiga toxin into cells. Zentralbl. Bakteriol., 1993, 278(2-3), 296-305.

http://dx.doi.org/10.1016/S0934-8840(11)80846-7 PMID: 8347933

[35] Sandvig, K.; Grimmer, S.; Lauvrak, S.U.; Torgersen, M.L.; Skretting, G.; van Deurs, B.; Iversen, T.G. Pathways followed by ricin and Shiga toxin into cells. Histochem. Cell Biol., 2002, 117(2), 131-141.

http://dx.doi.org/10.1007/s00418-001-0346-2 PMID: 11935289

[36] Melton-Celsa, A.R.; Shiga, toxin classification, structure, and function Microbiol Spectr, 2014, 2(4) EHEC-0024-2013

[37] Endo, Y.; Tsurugi, K.; Yutsudo, T.; Takeda, Y.; Ogasawara, T.; Igarashi, K. Site of action of a Vero toxin (VT2) from Escherichia coli $\mathrm{O} 157: \mathrm{H} 7$ and of Shiga toxin on eukaryotic ribosomes. RNA Nglycosidase activity of the toxins. Eur. J. Biochem., 1988, 171(1-2), 45-50.

http://dx.doi.org/10.1111/j.1432-1033.1988.tb13756.x PMID: 3276522

[38] Furutani, M.; Kashiwagi, K.; Ito, K.; Endo, Y.; Igarashi, K. Comparison of the modes of action of a Vero toxin (a Shiga-like toxin) from Escherichia coli, of ricin, and of alpha-sarcin. Arch. Biochem. Biophys., 1992, 293(1), 140-146.

http://dx.doi.org/10.1016/0003-9861(92)90376-8 PMID: 1731630

[39] Hall, G.; Kurosawa, S.; Stearns-Kurosawa, D.J. Shiga toxin therapeutics: beyond neutralization. Toxins (Basel), 2017, 9(9), E291. http://dx.doi.org/10.3390/toxins9090291 PMID: 28925976

[40] Iordanov, M.S.; Paranjape, J.M.; Zhou, A.; Wong, J.; Williams, B.R.; Meurs, E.F.; Silverman, R.H.; Magun, B.E. Activation of p38 mitogen-activated protein kinase and c-Jun $\mathrm{NH}(2)$-terminal kinase by double-stranded RNA and encephalomyocarditis virus: involvement of RNase L, protein kinase R, and alternative pathways. Mol. Cell. Biol., 2000, 20(2), 617-627.

http://dx.doi.org/10.1128/MCB.20.2.617-627.2000 PMID: 10611240

[41] Morace, I.; Pilz, R.; Federico, G.; Jennemann, R.; Krunic, D.; Nordström, V.; von Gerichten, J.; Marsching, C.; Schieß1, I.M.; Müthing, J.; Wunder, C.; Johannes, L.; Sandhoff, R.; Gröne, H.J. Renal globotriaosylceramide facilitates tubular albumin absorption and its inhibition protects against acute kidney injury. Kidney Int., 2019, $96(2), 327-341$.

http://dx.doi.org/10.1016/j.kint.2019.02.010 PMID: 31101366

[42] Iwamura, K.; Furukawa, K.; Uchikawa, M.; Sojka, B.N.; Kojima, Y.; Wiels, J.; Shiku, H.; Urano, T.; Furukawa, K. The blood group $\mathrm{P} 1$ synthase gene is identical to the Gb3/CD77 synthase gene. A clue to the solution of the $\mathrm{P} 1 / \mathrm{P} 2 / \mathrm{p}$ puzzle. J. Biol. Chem., 2003, 278(45), 44429-44438.

http://dx.doi.org/10.1074/jbc.M301609200 PMID: 12888565

[43] Naiki, M.; Kato, M. Immunological identification of blood group $\mathrm{Pk}$ antigen on normal human erythrocytes and isolation of anti-Pk with different affinity. Vox Sang., 1979, 37(1), 30-38. http://dx.doi.org/10.1159/000466879 PMID: 494578 
[44] Knapp, W.; Dörken, B.; Rieber, P.; Schmidt, R.E.; Stein, H.; von dem Borne, A.E. CD antigens 1989. Blood, 1989, 74(4), 14481450 .

http://dx.doi.org/10.1182/blood.V74.4.1448.1448 PMID: 2765668

[45] Mangeney, M.; Richard, Y.; Coulaud, D.; Tursz, T.; Wiels, J. CD77: an antigen of germinal center B cells entering apoptosis. Eur. J. Immunol., 1991, 21(5), 1131-1140.

http://dx.doi.org/10.1002/eji.1830210507 PMID: 1709864

[46] Sueoka, H.; Aoki, M.; Tsukimura, T.; Togawa, T.; Sakuraba, H. Distributions of globotriaosylceramide isoforms, and globotriaosylsphingosine and its analogues in an $\alpha$-galactosidase a knockout mouse, a model of fabry disease. PLoS One, 2015, 10(12), e0144958.

http://dx.doi.org/10.1371/journal.pone.0144958 PMID: 26661087

[47] Kovbasnjuk, O.; Edidin, M.; Donowitz, M. Role of lipid rafts in Shiga toxin 1 interaction with the apical surface of Caco-2 cells. $J$. Cell Sci., 2001, 114(Pt 22), 4025-4031.

PMID: 11739634

[48] Kavaliauskiene, S.; Nymark, C.M.; Bergan, J.; Simm, R.; Sylvänne, T.; Simolin, H.; Ekroos, K.; Skotland, T.; Sandvig, K. Cell density-induced changes in lipid composition and intracellular trafficking. Cell. Mol. Life Sci., 2014, 71(6), 1097-1116. http://dx.doi.org/10.1007/s00018-013-1441-y PMID: 23921715

[49] Brigotti, M. The interactions of human neutrophils with shiga toxins and related plant toxins: danger or safety? Toxins (Basel), 2012, 4(3), 157-190

http://dx.doi.org/10.3390/toxins4030157 PMID: 22741061

[50] Brigotti, M.; Carnicelli, D.; Ravanelli, E.; Barbieri, S.; Ricci, F.; Bontadini, A.; Tozzi, A.E.; Scavia, G.; Caprioli, A.; Tazzari, P.L. Interactions between Shiga toxins and human polymorphonuclear leukocytes. J. Leukoc. Biol., 2008, 84(4), 1019-1027. http://dx.doi.org/10.1189/jlb.0308157 PMID: 18625912

[51] Brigotti, M.; Tazzari, P.L.; Ravanelli, E.; Carnicelli, D.; Rocchi, L.; Arfilli, V.; Scavia, G.; Minelli, F.; Ricci, F.; Pagliaro, P.; Ferretti, A.V.; Pecoraro, C.; Paglialonga, F.; Edefonti, A.; Procaccino, M.A.; Tozzi, A.E.; Caprioli, A. Clinical relevance of shiga toxin concentrations in the blood of patients with hemolytic uremic syndrome. Pediatr. Infect. Dis. J., 2011, 30(6), 486-490. http://dx.doi.org/10.1097/INF.0b013e3182074d22 PMID: 21164386

[52] te Loo, D.M.; Monnens, L.A.; van Der Velden, T.J.; Vermeer, M.A.; Preyers, F.; Demacker, P.N.; van Den Heuvel, L.P.; van Hinsbergh, V.W. Binding and transfer of verocytotoxin by polymorphonuclear leukocytes in hemolytic uremic syndrome. Blood, 2000, 95(11), 3396-3402.

http://dx.doi.org/10.1182/blood.V95.11.3396 PMID: 10828021

[53] Te Loo, D.M.; van Hinsbergh, V.W.; van den Heuvel, L.P.; Monnens, L.A. Detection of verocytotoxin bound to circulating polymorphonuclear leukocytes of patients with hemolytic uremic syndrome. J. Am. Soc. Nephrol., 2001, 12(4), 800-806.

PMID: 11274241

[54] Brigotti, M.; Carnicelli, D.; Arfilli, V.; Tamassia, N.; Borsetti, F.; Fabbri, E.; Tazzari, P.L.; Ricci, F.; Pagliaro, P.; Spisni, E.; Cassatella, M.A. Identification of TLR4 as the receptor that recognizes Shiga toxins in human neutrophils. J. Immunol., 2013, 191(9), 4748-4758.

http://dx.doi.org/10.4049/jimmunol.1300122 PMID: 24068665

[55] Ståhl, A.L.; Arvidsson, I.; Johansson, K.E.; Chromek, M.; Rebetz, J.; Loos, S.; Kristoffersson, A.C.; Békássy, Z.D.; Mörgelin, M.; Karpman, D. A novel mechanism of bacterial toxin transfer within host blood cell-derived microvesicles. PLoS Pathog., 2015, 11(2), e1004619.

http://dx.doi.org/10.1371/journal.ppat.1004619 PMID: 25719452

[56] Pinto, A.; Cangelosi, A.; Geoghegan, P.A.; Goldstein, J. Dexamethasone prevents motor deficits and neurovascular damage produced by shiga toxin 2 and lipopolysaccharide in the mouse striatum. Neuroscience, 2017, 344, 25-38.

http://dx.doi.org/10.1016/j.neuroscience.2016.12.036 PMID: 28042026

[57] Exeni, R.A.; Fernandez-Brando, R.J.; Santiago, A.P.; Fiorentino, G.A.; Exeni, A.M.; Ramos, M.V.; Palermo, M.S. Pathogenic role of inflammatory response during Shiga toxin-associated hemolytic uremic syndrome (HUS). Pediatr. Nephrol., 2018, 33(11), 20572071 .

http://dx.doi.org/10.1007/s00467-017-3876-0 PMID: 29372302
[58] Eisenhauer, P.B.; Chaturvedi, P.; Fine, R.E.; Ritchie, A.J.; Pober, J.S.; Cleary, T.G.; Newburg, D.S. Tumor necrosis factor alpha increases human cerebral endothelial cell $\mathrm{Gb3}$ and sensitivity to Shiga toxin. Infect. Immun., 2001, 69(3), 1889-1894. http://dx.doi.org/10.1128/IAI.69.3.1889-1894.2001 PMID: 11179369

[59] Ito, M.; Shiozaki, A.; Shimizu, M.; Saito, S. Hemolytic-uremic syndrome with acute encephalopathy in a pregnant woman infected with epidemic enterohemorrhagic Escherichia coli: characteristic brain images and cytokine profiles. Int. J. Infect. Dis., 2015, 34, 119-121.

http://dx.doi.org/10.1016/j.ijid.2015.03.024 PMID: 25841635

[60] Shimizu, M.; Nakayama, Y.; Taniguchi, T. Successful treatment of enterohemorrhagic Escherichia coli O111-induced acute encephalopathy and hemolytic-uremic syndrome with plasma diafiltration. Ther. Apher. Dial., 2014, 18(5), 516-518.

http://dx.doi.org/10.1111/1744-9987.12165 PMID: 24467800

[61] Karpman, D.; Connell, H.; Svensson, M.; Scheutz, F.; Alm, P.; Svanborg, C. The role of lipopolysaccharide and Shiga-like toxin in a mouse model of Escherichia coli $\mathrm{O} 157: \mathrm{H} 7$ infection. J. Infect. Dis., 1997, 175(3), 611-620.

http://dx.doi.org/10.1093/infdis/175.3.611 PMID: 9041333

[62] Jing, W.; Jabbari, B.; Vaziri, N.D. Uremia induces upregulation of cerebral tissue oxidative/inflammatory cascade, down-regulation of Nrf2 pathway and disruption of blood brain barrier. Am. J. Transl. Res., 2018, 10(7), 2137-2147.

PMID: 30093950

[63] Obata, F.; Tohyama, K.; Bonev, A.D.; Kolling, G.L.; Keepers, T.R.; Gross, L.K.; Nelson, M.T.; Sato, S.; Obrig, T.G. Shiga toxin 2 affects the central nervous system through receptor globotriaosylceramide localized to neurons. J. Infect. Dis., 2008, 198(9), 1398 1406

http://dx.doi.org/10.1086/591911 PMID: 18754742

[64] Magnus, T.; Röther, J.; Simova, O.; Meier-Cillien, M.; Repenthin, J.; Möller, F.; Gbadamosi, J.; Panzer, U.; Wengenroth, M.; Hagel, C.; Kluge, S.; Stahl, R.K.; Wegscheider, K.; Urban, P.; Eckert, B.; Glatzel, M.; Fiehler, J.; Gerloff, C. The neurological syndrome in adults during the 2011 northern German E. coli serotype O104:H4 outbreak. Brain, 2012, 135(Pt 6), 1850-1859.

http://dx.doi.org/10.1093/brain/aws090 PMID: 22539260

[65] López, M.; Huete, I.; Hernández, M. Acute cerebrovascular events associated to hemolytic uremic syndrome: description of two pediatric cases. Rev. Chil. Pediatr., 2017, 88(5), 640-646.

PMID: 29546950

[66] Imataka, G.; Wake, K.; Suzuki, M.; Yamanouchi, H.; Arisaka, O. Acute encephalopathy associated with hemolytic uremic syndrome caused by Escherichia coli O157: H7 and rotavirus infection. Eur. Rev. Med. Pharmacol. Sci., 2015, 19(10), 1842-1844. PMID: 26044229

[67] Hamano, S.; Nakanishi, Y.; Nara, T.; Seki, T.; Ohtani, T.; Oishi, T.; Joh, K.; Oikawa, T.; Muramatsu, Y.; Ogawa, Y. Neurological manifestations of hemorrhagic colitis in the outbreak of Escherichia coli O157:H7 infection in Japan. Acta Paediatr., 1993, 82(5), 454-458.

http://dx.doi.org/10.1111/j.1651-2227.1993.tb12721.x PMID: 8518521

[68] Pape, L.; Hartmann, H.; Bange, F.C.; Suerbaum, S.; Bueltmann, E. Ahlenstiel-Grunow, T. Eculizumab in typical hemolytic uremic Syndrome (HUS) with neurological involvement. Medicine (Baltimore), 2015, 94(24), e1000.

http://dx.doi.org/10.1097/MD.0000000000001000 PMID 26091445

[69] Nathanson, S.; Kwon, T.; Elmaleh, M.; Charbit, M.; Launay, E.A.; Harambat, J.; Brun, M.; Ranchin, B.; Bandin, F.; Cloarec, S.; Bourdat-Michel, G.; Piètrement, C.; Champion, G.; Ulinski, T.; Deschênes, G. Acute neurological involvement in diarrheaassociated hemolytic uremic syndrome. Clin. J. Am. Soc. Nephrol., 2010, 5(7), 1218-1228.

http://dx.doi.org/10.2215/CJN.08921209 PMID: 20498239

[70] Schuppner, R.; Maehlmann, J.; Dirks, M.; Worthmann, H.; Tryc, A.B.; Sandorski, K.; Bahlmann, E.; Kielstein, J.T.; Giesemann, A.M.; Lanfermann, H.; Weissenborn, K. Neurological sequelae in adults after $E$. coli o104: h4 infection-induced hemolytic-uremic syndrome. Medicine (Baltimore), 2016, 95(6), e2337. http://dx.doi.org/10.1097/MD.0000000000002337 PMID: 26871766 
[71] Weissenborn, K.; Donnerstag, F.; Kielstein, J.T.; Heeren, M.; Worthmann, H.; Hecker, H.; Schmitt, R.; Schiffer, M.; Pasedag, T.; Schuppner, R.; Tryc, A.B.; Raab, P.; Hartmann, H.; Ding, X.Q.; Hafer, C.; Menne, J.; Schmidt, B.M.; Bültmann, E.; Haller, H.; Dengler, R.; Lanfermann, H.; Giesemann, A.M. Neurologic manifestations of $E$. coli infection-induced hemolytic-uremic syndrome in adults. Neurology, 2012, 79(14), 1466-1473.

http://dx.doi.org/10.1212/WNL.0b013e31826d5f26 PMID: 22993286

[72] Matthies, J.; Hünseler, C.; Ehren, R.; Volland, R.; Körber, F.; Hoppe, B.; Weber, L.T.; Habbig, S. Extrarenal manifestations in Shigatoxin-associated haemolytic uremic syndrome. Klin. Padiatr., 2016, 228(4), 181-188.

http://dx.doi.org/10.1055/s-0042-108444 PMID: 27294341

[73] Steinborn, M.; Leiz, S.; Rüdisser, K.; Griebel, M.; Harder, T.; Hahn, H. CT and MRI in haemolytic uraemic syndrome with central nervous system involvement: distribution of lesions and prognostic value of imaging findings. Pediatr. Radiol., 2004, 34(10), $805-810$

http://dx.doi.org/10.1007/s00247-004-1289-2 PMID: 15378218

[74] Trachtman, H.; Austin, C.; Lewinski, M.; Stahl, R.A. Renal and neurological involvement in typical Shiga toxin-associated HUS. Nat. Rev. Nephrol., 2012, 8(11), 658-669.

http://dx.doi.org/10.1038/nrneph.2012.196 PMID: 22986362

[75] Yahata, Y.; Misaki, T.; Ishida, Y.; Nagira, M.; Watahiki, M.; Isobe, J.; Terajima, J.; Iyoda, S.; Mitobe, J.; Ohnishi, M.; Sata, T.; Taniguchi, K.; Tada, Y.; Okabe, N. E. coli O111 Outbreak Investigation Team. Epidemiological analysis of a large enterohaemorrhagic Escherichia coli $\mathrm{O} 111$ outbreak in Japan associated with haemolytic uraemic syndrome and acute encephalopathy. Epidemiol. Infect., 2015, 143(13), 2721-2732.

http://dx.doi.org/10.1017/S0950268814003641 PMID: 25600435

[76] Loudon, S.E. Blinded by shiga toxin-producing O104 Escherichia coli and hemolytic uremic syndrome. J. Pediatr, 2014, 165(2), 410410 e 1.

http://dx.doi.org/10.1016/j.jpeds.2014.04.008

[77] Obata, F. Influence of Escherichia coli shiga toxin on the mammalian central nervous system. Adv. Appl. Microbiol., 2010, 71, 1-19. http://dx.doi.org/10.1016/S0065-2164(10)71001-7 PMID: 20378049

[78] Signorini, E.; Lucchi, S.; Mastrangelo, M.; Rapuzzi, S.; Edefonti, A.; Fossali, E. Central nervous system involvement in a child with hemolytic uremic syndrome. Pediatr. Nephrol., 2000, 14(10-11), 990-992. http://dx.doi.org/10.1007/s004670050059 PMID: 10975313

[79] Carnicelli, D.; Arfilli, V.; Ricci, F.; Velati, C.; Tazzari, P.L.; Brigotti, M. The Antibiotic Polymyxin B impairs the interactions between shiga toxins and human neutrophils. J. Immunol., 2016, 196(3), 1177-1185.

http://dx.doi.org/10.4049/jimmunol.1500671 PMID: 26695372

[80] Arfilli, V.; Carnicelli, D.; Rocchi, L.; Ricci, F.; Pagliaro, P.; Tazzari, P.L.; Brigotti, M. Shiga toxin 1 and ricin A chain bind to human polymorphonuclear leucocytes through a common receptor. Biochem. J., 2010, 432(1), 173-180.

http://dx.doi.org/10.1042/BJ20100455 PMID: 20809900

[81] Brigotti, M.; Tazzari, P.L.; Ravanelli, E.; Carnicelli, D.; Barbieri, S.; Rocchi, L.; Arfilli, V.; Scavia, G.; Ricci, F.; Bontadini, A.; Alfieri, R.R.; Petronini, P.G.; Pecoraro, C.; Tozzi, A.E.; Caprioli, A. Endothelial damage induced by Shiga toxins delivered by neutrophils during transmigration. J. Leukoc. Biol., 2010, 88(1), 201210 .

http://dx.doi.org/10.1189/jlb.0709475 PMID: 20371598

[82] Griener, T.P.; Mulvey, G.L.; Marcato, P.; Armstrong, G.D. Differential binding of Shiga toxin 2 to human and murine neutrophils. $J$. Med. Microbiol., 2007, 56(Pt 11), 1423-1430.

http://dx.doi.org/10.1099/jmm.0.47282-0 PMID: 17965340

[83] Ståhl, A.L.; Sartz, L.; Nelsson, A.; Békássy, Z.D.; Karpman, D. Shiga toxin and lipopolysaccharide induce platelet-leukocyte aggregates and tissue factor release, a thrombotic mechanism in hemolytic uremic syndrome. PLoS One, 2009, 4(9), e6990. http://dx.doi.org/10.1371/journal.pone.0006990 PMID: 19750223

[84] Tazzari, P.L.; Ricci, F.; Carnicelli, D.; Caprioli, A.; Tozzi, A.E.; Rizzoni, G.; Conte, R.; Brigotti, M. Flow cytometry detection of Shiga toxins in the blood from children with hemolytic uremic syndrome. Cytometry B Clin. Cytom., 2004, 61(1), 40-44. http://dx.doi.org/10.1002/cyto.b.20022 PMID: 15351981

[85] Kanazawa, K.; Sato, Y.; Ohki, K.; Okimura, K.; Uchida, Y.; Shindo, M.; Sakura, N. Contribution of each amino acid residue in polymyxin $\mathrm{B}(3)$ to antimicrobial and lipopolysaccharide binding activity. Chem. Pharm. Bull. (Tokyo), 2009, 57(3), 240-244. http://dx.doi.org/10.1248/cpb.57.240 PMID: 19252313

[86] Percivalle, E.; Monzillo, V.; Pauletto, A.; Marone, P.; Imberti, R. Colistin inhibits E. coli O157:H7 Shiga-like toxin release, binds endotoxins and protects Vero cells. New Microbiol., 2016, 39(2), 119-123.

PMID: 27196550

[87] Zavascki, A.P.; Goldani, L.Z.; Cao, G.; Superti, S.V.; Lutz, L.; Barth, A.L.; Ramos, F.; Boniatti, M.M.; Nation, R.L.; Li, J. Pharmacokinetics of intravenous polymyxin B in critically ill patients. Clin. Infect. Dis., 2008, 47(10), 1298-1304. http://dx.doi.org/10.1086/592577 PMID: 18840079

[88] Kwa, A.; Kasiakou, S.K.; Tam, V.H.; Falagas, M.E. Polymyxin B: similarities to and differences from colistin (polymyxin E). Expert Rev. Anti Infect. Ther., 2007, 5(5), 811-821.

http://dx.doi.org/10.1586/14787210.5.5.811 PMID: 17914915

[89] Cai, Y.; Lee, W.; Kwa, A.L. Polymyxin B versus colistin: an update. Expert Rev. Anti Infect. Ther., 2015, 13(12), 1481-1497. http://dx.doi.org/10.1586/14787210.2015.1093933 PMID: 26488563

[90] Macher, B.A.; Klock, J.C. Isolation and chemical characterization of neutral glycosphingolipids of human neutrophils. J. Biol. Chem., 1980, 255(5), 2092-2096.

PMID: 7354081

[91] Dijkmans, A.C.; Zacarías, N.V.O.; Burggraaf, J.; Mouton, J.W.; Wilms, E.B.; van Nieuwkoop, C.; Touw, D.J.; Stevens, J.; Kamerling, I.M.C. Fosfomycin: pharmacological, clinical and future perspectives. Antibiotics (Basel), 2017, 6(4), E24.

http://dx.doi.org/10.3390/antibiotics6040024 PMID: 29088073

[92] Tajiri, H.; Nishi, J.; Ushijima, K.; Shimizu, T.; Ishige, T.; Shimizu, M.; Tanaka, H.; Brooks, S. A role for fosfomycin treatment in children for prevention of haemolytic-uraemic syndrome accompanying Shiga toxin-producing Escherichia coli infection. Int. J. Antimicrob. Agents, 2015, 46(5), 586-589.

http://dx.doi.org/10.1016/j.ijantimicag.2015.08.006 PMID: 26391378

[93] Ikeda, K.; Ida, O.; Kimoto, K.; Takatorige, T.; Nakanishi, N.; Tatara, K. Effect of early fosfomycin treatment on prevention of hemolytic uremic syndrome accompanying Escherichia coli O157:H7 infection. Clin. Nephrol., 1999, 52(6), 357-362. PMID: 10604643

[94] Hosaka, T.; Nakamagoe, K.; Tamaoka, A. Hemolytic uremic syndrome-associated encephalopathy successfully treated with corticosteroids. Intern. Med., 2017, 56(21), 2937-2941.

http://dx.doi.org/10.2169/internalmedicine.8341-16 PMID: 28943538

[95] Ohara, T.; Kojio, S.; Taneike, I.; Nakagawa, S.; Gondaira, F.; Tamura, Y.; Gejyo, F.; Zhang, H.M.; Yamamoto, T. Effects of azithromycin on shiga toxin production by Escherichia coli and subsequent host inflammatory response. Antimicrob. Agents Chemother., 2002, 46(11), 3478-3483.

http://dx.doi.org/10.1128/AAC.46.11.3478-3483.2002 PMID: 12384353

[96] Matsushiro, A.; Sato, K.; Miyamoto, H.; Yamamura, T.; Honda, T. Induction of prophages of enterohemorrhagic Escherichia coli O157:H7 with norfloxacin. J. Bacteriol., 1999, 181(7), 2257-2260. http://dx.doi.org/10.1128/JB.181.7.2257-2260.1999 PMID: 10094706

[97] Zhang, X.; McDaniel, A.D.; Wolf, L.E.; Keusch, G.T.; Waldor, M.K.; Acheson, D.W. Quinolone antibiotics induce Shiga toxinencoding bacteriophages, toxin production, and death in mice. $J$. Infect. Dis., 2000, 181(2), 664-670.

http://dx.doi.org/10.1086/315239 PMID: 10669353

[98] Fujii, T.; Kadota, J.; Morikawa, T.; Matsubara, Y.; Kawakami, K.; Iida, K.; Shirai, R.; Taniguchi, H.; Kaseda, M.; Kawamoto, S.; Kohno, S. Inhibitory effect of erythromycin on interleukin 8 production by 1 alpha,25-dihydroxyvitamin D3-stimulated THP-1 cells. Antimicrob. Agents Chemother., 1996, 40(6), 1548-1551. http://dx.doi.org/10.1128/AAC.40.6.1548 PMID: 8726037

[99] Khan, A.A.; Slifer, T.R.; Araujo, F.G.; Remington, J.S. Effect of clarithromycin and azithromycin on production of cytokines by 
human monocytes. Int. J. Antimicrob. Agents, 1999, 11(2), 121132.

http://dx.doi.org/10.1016/S0924-8579(98)00091-0 PMID: 10221415

[100] Rubin, B.K.; Druce, H.; Ramirez, O.E.; Palmer, R. Effect of clarithromycin on nasal mucus properties in healthy subjects and in patients with purulent rhinitis. Am. J. Respir. Crit. Care Med., 1997, 155(6), 2018-2023.

http://dx.doi.org/10.1164/ajrccm.155.6.9196110 PMID: 9196110

[101] Rubin, B.K.; Tamaoki, J. Macrolide antibiotics as biological response modifiers. Curr. Opin. Investig. Drugs, 2000, 1(2), 169-172. PMID: 11249569

[102] Gianantonio, C.; Vitacco, M.; Mendilaharzu, F.; Rutty, A.; Mendilaharzu, J. The hemolytic-uremic syndrome. J. Pediatr., 1964, 64, 478-491.

http://dx.doi.org/10.1016/S0022-3476(64)80337-1 PMID: 14141006

[103] Bell, W.R.; Braine, H.G.; Ness, P.M.; Kickler, T.S. Improved survival in thrombotic thrombocytopenic purpura-hemolytic uremic syndrome. Clinical experience in 108 patients. N. Engl. J. Med., 1991, 325(6), 398-403.

http://dx.doi.org/10.1056/NEJM199108083250605 PMID: 2062331

[104] Perez, N.; Spizzirri, F.; Rahman, R.; Suarez, A.; Larrubia, C.; Lasarte, P. Steroids in the hemolytic uremic syndrome. Pediatr. Nephrol., 1998, 12(2), 101-104.

http://dx.doi.org/10.1007/s004670050413 PMID: 9543364

[105] Fujii, J.; Kinoshita, Y.; Matsukawa, A.; Villanueva, S.Y.; Yutsudo, T.; Yoshida, S. Successful steroid pulse therapy for brain lesion caused by Shiga toxin 2 in rabbits. Microb. Pathog., 2009, 46(4), 179-184.

http://dx.doi.org/10.1016/j.micpath.2009.01.005 PMID: 19490831

[106] Takanashi, J.; Taneichi, H.; Misaki, T.; Yahata, Y.; Okumura, A.; Ishida, Y.; Miyawaki, T.; Okabe, N.; Sata, T.; Mizuguchi, M. Clinical and radiologic features of encephalopathy during $2011 E$ coli O111 outbreak in Japan. Neurology, 2014, 82(7), 564-572. http://dx.doi.org/10.1212/WNL.0000000000000120 PMID: 24443449

[107] Oki, E.; Tsuruga, K.; Tsugawa, K.; Suzuki, K.; Shinagawa, T.; Nakahata, T.; Ito, E.; Tanaka, H. Alternative treatment for systemic involvement in a child with postdiarrheal hemolytic-uremic syndrome. Clin. Nephrol., 2008, 70(4), 354-356.

http://dx.doi.org/10.5414/CNP70354 PMID: 18826863

[108] Yoshimitsu, M.; Hayashi, N.; Kaneko, Y.; Doyama, H. An adult case of combined encephalopathy and hemolytic uremic syndrome caused by Escherichia coli O157. Nippon Shokakibyo Gakkai Zasshi, 2011, 108(1), 74-79.

PMID: 21212597

[109] Yada, N.; Fujioka, M.; Bennett, C.L.; Inoki, K.; Miki, T.; Watanabe, A.; Yoshida, T.; Hayakawa, M.; Matsumoto, M.; Fujimura, Y. STEC:O111-HUS complicated by acute encephalopathy in a young girl was successfully treated with a set of hemodiafiltration, steroid pulse, and soluble thrombomodulin under plasma exchange. Clin. Case Rep., 2015, 3(4), 208-212.

http://dx.doi.org/10.1002/ccr3.196 PMID: 25914810

[110] Kuroda, M.; Shimizu, M.; Inoue, N.; Ikeno, I.; Nakagawa, H.; Yokoi, A.; Niida, Y.; Konishi, M.; Kaneda, H.; Igarashi, N.; Yamahana, J.; Taneichi, H.; Kanegane, H.; Ito, M.; Saito, S.; Furuichi, K.; Wada, T.; Nakagawa, M.; Yokoyama, H.; Yachie, A. Serum tau protein as a marker of disease activity in enterohemorrhagic Escherichia coli O111-induced hemolytic uremic syndrome. Neurochem. Int., 2015, 85-86, 24-30.

http://dx.doi.org/10.1016/j.neuint.2015.04.003 PMID: 25895963

[111] Förster, C.; Waschke, J.; Burek, M.; Leers, J.; Drenckhahn, D. Glucocorticoid effects on mouse microvascular endothelial barrier permeability are brain specific. J. Physiol., 2006, 573(Pt 2), 413425.

http://dx.doi.org/10.1113/jphysiol.2006.106385 PMID: 16543270

[112] Liu, C.C.; Chien, C.H.; Lin, M.T. Glucocorticoids reduce interleukin-1 concentration and result in neuroprotective effects in rat heatstroke. J. Physiol., 2000, 527(Pt 2), 333-343.

http://dx.doi.org/10.1111/j.1469-7793.2000.t01-1-00333.x PMID: 10970434

[113] Pinto, A.; Carnuccio, R.; Sorrentino, R.; Di Rosa, M. The inhibition of platelet aggregation by activated macrophages is blocked by dexamethasone. Pharmacol. Res., 1993, 27(2), 165-172. http://dx.doi.org/10.1006/phrs.1993.1016 PMID: 8474960

[114] Gómez, S.A.; Fernández, G.C.; Vanzulli, S.; Dran, G.; Rubel, C.; Berki, T.; Isturiz, M.A.; Palermo, M.S. Endogenous glucocorticoids attenuate Shiga toxin-2-induced toxicity in a mouse model of haemolytic uraemic syndrome. Clin. Exp. Immunol., 2003, 131(2), 217-224.

http://dx.doi.org/10.1046/j.1365-2249.2003.02057.x PMID: 12562380

[115] Pinto, A.; Jacobsen, M.; Geoghegan, P.A.; Cangelosi, A.; Cejudo, M.L.; Tironi-Farinati, C.; Goldstein, J. Dexamethasone rescues neurovascular unit integrity from cell damage caused by systemic administration of shiga toxin 2 and lipopolysaccharide in mice motor cortex. PLoS One, 2013, 8(7), e70020.

http://dx.doi.org/10.1371/journal.pone.0070020 PMID: 23894578

[116] Pinto, A.; Berdasco, C.; Arenas-Mosquera, D.; Cangelosi, A.; Geoghegan, P.A.; Nuñez, M.C.; Goldstein, J. Anti-inflammatory agents reduce microglial response, demyelinating process and neuronal toxin uptake in a model of encephalopathy produced by Shiga Toxin 2. Int. J. Med. Microbiol., 2018, 308(8), 1036-1042. http://dx.doi.org/10.1016/j.ijmm.2018.09.007 PMID: 30314914

[117] Wu, J.J.; Feldman, S.R.; Lebwohl, M. Therapy for severe psoriasis., 2017.

[118] Haraoui, B.; Bykerk, V. Etanercept in the treatment of rheumatoid arthritis. Ther. Clin. Risk Manag., 2007, 3(1), 99-105. http://dx.doi.org/10.2147/tcrm.2007.3.1.99 PMID: 18360618

[119] Mohler, K.M.; Torrance, D.S.; Smith, C.A.; Goodwin, R.G.; Stremler, K.E.; Fung, V.P.; Madani, H.; Widmer, M.B. Soluble tumor necrosis factor (TNF) receptors are effective therapeutic agents in lethal endotoxemia and function simultaneously as both TNF carriers and TNF antagonists. J. Immunol., 1993, 151(3), 1548-1561. PMID: 8393046

[120] Menter, A.; Gottlieb, A.; Feldman, S.R.; Van Voorhees, A.S Leonardi, C.L.; Gordon, K.B.; Lebwohl, M.; Koo, J.Y.; Elmets, C.A.; Korman, N.J.; Beutner, K.R.; Bhushan, R. Guidelines of care for the management of psoriasis and psoriatic arthritis: Section 1. Overview of psoriasis and guidelines of care for the treatment of psoriasis with biologics. J. Am. Acad. Dermatol., 2008, 58(5), 826850.

http://dx.doi.org/10.1016/j.jaad.2008.02.039 PMID: 18423260

[121] Goldstein, J.; Carden, T.R.; Perez, M.J.; Taira, C.A.; Höcht, C.; Gironacci, M.M. Angiotensin-(1-7) protects from brain damage induced by shiga toxin 2-producing enterohemorrhagic Escherichia coli. Am. J. Physiol. Regul. Integr. Comp. Physiol., 2016, 311(6), R1173-R1185.

http://dx.doi.org/10.1152/ajpregu.00467.2015 PMID: 27681328

[122] Bennion, D.M.; Haltigan, E.; Regenhardt, R.W.; Steckelings, U.M.; Sumners, C. Neuroprotective mechanisms of the ACE2angiotensin-(1-7)-Mas axis in stroke. Curr. Hypertens. Rep., 2015, $17(2), 3$.

http://dx.doi.org/10.1007/s1 1906-014-0512-2 PMID: 25620630

[123] Regenhardt, R.W.; Bennion, D.M.; Sumners, C. Cerebroprotective action of angiotensin peptides in stroke. Clin. Sci. (Lond.), 2014, 126(3), 195-205.

http://dx.doi.org/10.1042/CS20130324 PMID: 24102099

[124] Regenhardt, R.W.; Mecca, A.P.; Desland, F.; Ritucci-Chinni, P.F.; Ludin, J.A.; Greenstein, D.; Banuelos, C.; Bizon, J.L.; Reinhard, M.K.; Sumners, C. Centrally administered angiotensin-(1-7) increases the survival of stroke-prone spontaneously hypertensive rats. Exp. Physiol., 2014, 99(2), 442-453.

http://dx.doi.org/10.1113/expphysiol.2013.075242 PMID: 24142453

[125] Chang, A.Y.; Li, F.C.; Huang, C.W.; Wu, J.C.; Dai, K.Y.; Chen, C.H.; Li, S.H.; Su, C.H.; Wu, R.W. Interplay between brain stem angiotensins and monocyte chemoattractant protein-1 as a novel mechanism for pressor response after ischemic stroke. Neurobiol. Dis., 2014, 71, 292-304. http://dx.doi.org/10.1016/j.nbd.2014.08.005 PMID: 25131447

[126] Chen, J.; Zhao, Y.; Chen, S.; Wang, J.; Xiao, X.; Ma, X.; Penchikala, M.; Xia, H.; Lazartigues, E.; Zhao, B.; Chen, Y. Neuronal over-expression of ACE2 protects brain from ischemia-induced damage. Neuropharmacology, 2014, 79, 550-558. http://dx.doi.org/10.1016/j.neuropharm.2014.01.004 PMID 24440367

[127] Zheng, J.; Li, G.; Chen, S.; Bihl, J.; Buck, J.; Zhu, Y.; Xia, H.; Lazartigues, E.; Chen, Y.; Olson, J.E. Activation of the ACE2/Ang- 
(1-7)/Mas pathway reduces oxygen-glucose deprivation-induced tissue swelling, ROS production, and cell death in mouse brain with angiotensin II overproduction. Neuroscience, 2014, 273, 3951 .

http://dx.doi.org/10.1016/j.neuroscience.2014.04.060 PMID: 24814023

[128] da Silveira, K.D.; Coelho, F.M.; Vieira, A.T.; Sachs, D.; Barroso, L.C.; Costa, V.V.; Bretas, T.L.; Bader, M.; de Sousa, L.P.; da Silva, T.A.; dos Santos, R.A.; Simões e Silva, A.C.; Teixeira, M.M. Anti-inflammatory effects of the activation of the angiotensin-(1-7) receptor, MAS, in experimental models of arthritis. J. Immunol., 2010, 185(9), 5569-5576. http://dx.doi.org/10.4049/jimmunol.1000314 PMID: 20935211

[129] Giani, J.F.; Muñoz, M.C.; Pons, R.A.; Cao, G.; Toblli, J.E.; Turyn, D.; Dominici, F.P. Angiotensin-(1-7) reduces proteinuria and diminishes structural damage in renal tissue of stroke-prone spontaneously hypertensive rats. Am. J. Physiol. Renal Physiol., 2011, 300(1), F272-F282.

http://dx.doi.org/10.1152/ajprenal.00278.2010 PMID: 20962118

[130] Tesanovic, S.; Vinh, A.; Gaspari, T.A.; Casley, D.; Widdop, R.E. Vasoprotective and atheroprotective effects of angiotensin (1-7) in apolipoprotein E-deficient mice. Arterioscler. Thromb. Vasc. Biol., 2010, 30(8), 1606-1613.

http://dx.doi.org/10.1161/ATVBAHA.110.204453 PMID: 20448208

[131] El-Hashim, A.Z.; Renno, W.M.; Raghupathy, R.; Abduo, H.T.; Akhtar, S.; Benter, I.F. Angiotensin-(1-7) inhibits allergic inflammation, via the MAS1 receptor, through suppression of ERK1/2and NF- $\kappa$ B-dependent pathways. Br. J. Pharmacol., 2012, 166(6), 1964-1976.

http://dx.doi.org/10.1111/j.1476-5381.2012.01905.x PMID: 22339213

[132] Wösten-van Asperen, R.M.; Lutter, R.; Specht, P.A.; Moll, G.N.; van Woensel, J.B.; van der Loos, C.M.; van Goor, H.; Kamilic, J.; Florquin, S.; Bos, A.P. Acute respiratory distress syndrome leads to reduced ratio of $\mathrm{ACE} / \mathrm{ACE} 2$ activities and is prevented by angiotensin-(1-7) or an angiotensin II receptor antagonist. J. Pathol., 2011, 225(4), 618-627.

http://dx.doi.org/10.1002/path.2987 PMID: 22009550

[133] Xu, P.; Sriramula, S.; Lazartigues, E. ACE2/ANG-(1-7)/Mas pathway in the brain: the axis of good. Am. J. Physiol. Regul. Integr. Comp. Physiol., 2011, 300(4), R804-R817. http://dx.doi.org/10.1152/ajpregu.00222.2010 PMID: 21178125

[134] Gironacci, M.M.; Longo Carbajosa, N.A.; Goldstein, J.; Cerrato, B.D. Neuromodulatory role of angiotensin-(1-7) in the central nervous system. Clin. Sci. (Lond.), 2013, 125(2), 57-65. http://dx.doi.org/10.1042/CS20120652 PMID: 23530669

[135] Poupko, J.M.; Baskin, S.I.; Moore, E. The pharmacological properties of anisodamine. J. Appl. Toxicol., 2007, 27(2), 116-121. http://dx.doi.org/10.1002/jat.1154 PMID: 17186568

[136] Guo, H.Y.; Lorenz, R.R.; Vanhoutte, P.M. Anisodamine inhibits non-selectively muscarinic receptors in isolated canine veins. Chin. Med. J. (Engl.), 1992, 105(1), 5-10.

PMID: 1576871

[137] Xiu, R.J.; Hammerschmidt, D.E.; Coppo, P.A.; Jacob, H.S. Anisodamine inhibits thromboxane synthesis, granulocyte aggregation, and platelet aggregation. A possible mechanism for its efficacy in bacteremic shock. JAMA, 1982, 247(10), 1458-1460. http://dx.doi.org/10.1001/jama.247.10.1458 PMID: 7057538

[138] Zhang, H.M.; Ou, Z.L.; Gondaira, F.; Ohmura, M.; Kojio, S.; Yamamoto, T. Protective effect of anisodamine against Shiga toxin-1: inhibition of cytokine production and increase in the survival of mice. J. Lab. Clin. Med., 2001, 137(2), 93-100.

http://dx.doi.org/10.1067/mlc.2001.112507 PMID: 11174465

[139] Balestracci, A. C3 levels and acute outcomes in Shiga toxin-related hemolytic uremic syndrome. Pediatr. Nephrol., 2020, 35, 331-339. PMID: 31475299

[140] Robson, W.L.; Leung, A.K.; Fick, G.H.; McKenna, A.I. Hypocomplementemia and leukocytosis in diarrhea-associated hemolytic uremic syndrome. Nephron, 1992, 62(3), 296-299.

http://dx.doi.org/10.1159/000187063 PMID: 1436342

[141] Thurman, J.M.; Marians, R.; Emlen, W.; Wood, S.; Smith, C.; Akana, H.; Holers, V.M.; Lesser, M.; Kline, M.; Hoffman, C.; Christen, E.; Trachtman, H. Alternative pathway of complement in children with diarrhea-associated hemolytic uremic syndrome. Clin. J. Am. Soc. Nephrol., 2009, 4(12), 1920-1924.

http://dx.doi.org/10.2215/CJN.02730409 PMID: 19820137

[142] Ferraris, J.R.; Ferraris, V.; Acquier, A.B.; Sorroche, P.B.; Saez, M.S.; Ginaca, A.; Mendez, C.F. Activation of the alternative pathway of complement during the acute phase of typical haemolytic uraemic syndrome. Clin. Exp. Immunol., 2015, 181(1), 118-125. http://dx.doi.org/10.1111/cei.12601 PMID: 25677399

[143] Ahlenstiel-Grunow, T.; Hachmeister, S.; Bange, F.C.; Wehling, C.; Kirschfink, M.; Bergmann, C.; Pape, L. Systemic complement activation and complement gene analysis in enterohaemorrhagic $E S$ cherichia coli-associated paediatric haemolytic uraemic syndrome. Nephrol. Dial. Transplant., 2016, 31(7), 1114-1121. http://dx.doi.org/10.1093/ndt/gfw078 PMID: 27190382

[144] Ağbaş, A.; Göknar, N.; Akıncı, N.; Yıldırım, Z.Y.; Taşdemir, M.; Benzer, M.; Gökçe, İ.; Candan, C.; Küçük, N.; Uzuner, S.; Özçelik, G.; Demirkol, D.; Sever, L.; Çalışkan, S. Outbreak of Shiga toxinproducing Escherichia-coli-associated hemolytic uremic syndrome in Istanbul in 2015: outcome and experience with eculizumab. $\mathrm{Pe}$ diatr. Nephrol., 2018, 33(12), 2371-2381.

http://dx.doi.org/10.1007/s00467-018-4033-0 PMID: 30159625

[145] Karnisova, L.; Hradsky, O.; Blahova, K.; Fencl, F.; Dolezel, Z.; Zaoral, T.; Zieg, J. Complement activation is associated with more severe course of diarrhea-associated hemolytic uremic syndrome, a preliminary study. Eur. J. Pediatr., 2018, 177(12), 1837-1844. http://dx.doi.org/10.1007/s00431-018-3255-2 PMID: 30251107

[146] Frémeaux-Bacchi, V.; Sellier-Leclerc, A.L.; Vieira-Martins, P.; Limou, S.; Kwon, T.; Lahoche, A.; Novo, R.; Llanas, B.; Nobili, F.; Roussey, G.; Cailliez, M.; Ulinski, T.; Deschênes, G.; Alberti, C.; Weill, F.X.; Mariani, P.; Loirat, C. Complement gene variants and Shiga Toxin-Producing Escherichia coli-associated hemolytic uremic syndrome: retrospective genetic and clinical study. Clin. J. Am. Soc. Nephrol., 2019, 14(3), 364-377.

http://dx.doi.org/10.2215/CJN.05830518 PMID: 30674459

[147] Kaplan, B.S.; Thomson, P.D.; MacNab, G.M. Letter: Serumcomplement levels in haemolytic-uraemic syndrome. Lancet, 1973, 2(7844), 1505-1506.

http://dx.doi.org/10.1016/S0140-6736(73)92782-7 PMID: 4129358

[148] Gitiaux, C.; Krug, P.; Grevent, D.; Kossorotoff, M.; Poncet, S.; Eisermann, M.; Oualha, M.; Boddaert, N.; Salomon, R.; Desguerre, I. Brain magnetic resonance imaging pattern and outcome in children with haemolytic-uraemic syndrome and neurological impairment treated with eculizumab. Dev. Med. Child Neurol., 2013, 55(8), 758-765.

http://dx.doi.org/10.1111/dmcn.12161 PMID: 23659643

[149] Krämer, J.; Deppe, M.; Göbel, K.; Tabelow, K.; Wiendl, H.; Meuth, S.G. Recovery of thalamic microstructural damage after Shiga toxin 2-associated hemolytic-uremic syndrome. J. Neurol. Sci., 2015, 356(1-2), 175-183. http://dx.doi.org/10.1016/j.jns.2015.06.045 PMID: 26189050

[150] Lapeyraque, A.L.; Malina, M.; Fremeaux-Bacchi, V.; Boppel, T.; Kirschfink, M.; Oualha, M.; Proulx, F.; Clermont, M.J.; Le Deist, F.; Niaudet, P.; Schaefer, F. Eculizumab in severe Shiga-toxinassociated HUS. N. Engl. J. Med., 2011, 364(26), 2561-2563. http://dx.doi.org/10.1056/NEJMc1100859 PMID: 21612462

[151] Mahat, U.; Matar, R.B.; Rotz, S.J. Use of complement monoclonal antibody eculizumab in Shiga toxin producing Escherichia coli associated hemolytic uremic syndrome: A review of current evidence. Pediatr. Blood Cancer, 2019, 66(11), e27913.

http://dx.doi.org/10.1002/pbc.27913 PMID: 31286658

[152] Saini, A.; Emke, A.R.; Silva, M.C.; Perlman, S.J. Response to Eculizumab in Escherichia coli O157: H7-induced hemolytic uremic syndrome with severe neurological manifestations. Clin. Pediatr. (Phila.), 2015, 54(4), 387-389. http://dx.doi.org/10.1177/0009922814534520 PMID: 24817079

[153] Dmytrijuk, A.; Robie-Suh, K.; Cohen, M.H.; Rieves, D.; Weiss, K.; Pazdur, R. FDA report: eculizumab (Soliris) for the treatment of patients with paroxysmal nocturnal hemoglobinuria. Oncologist, 2008, 13(9), 993-1000

http://dx.doi.org/10.1634/theoncologist.2008-0086 PMID 18784156

[154] Wijnsma, K.L.; Ter Heine, R.; Moes, D.J.A.R.; Langemeijer, S.; Schols, S.E.M.; Volokhina, E.B.; van den Heuvel, L.P.; Wetzels, J.F.M.; van de Kar, N.C.A.J.; Brüggemann, R.J. Pharmacology, pharmacokinetics and pharmacodynamics of eculizumab, and pos- 
sibilities for an individualized approach to eculizumab. Clin. Pharmacokinet., 2019, 58(7), 859-874.

http://dx.doi.org/10.1007/s40262-019-00742-8 PMID: 30758736

[155] Goldstein, J.; Loidl, C.F.; Creydt, V.P.; Boccoli, J.; Ibarra, C. Intracerebroventricular administration of Shiga toxin type 2 induces striatal neuronal death and glial alterations: an ultrastructural study. Brain Res., 2007, 1161, 106-115.

http://dx.doi.org/10.1016/j.brainres.2007.05.067 PMID: 17610852

[156] Gallo, E.G.; Gianantonio, C.A. Extrarenal involvement in diarrhoea-associated haemolytic-uraemic syndrome. Pediatr. Nephrol., 1995, $9(1), 117-119$.

http://dx.doi.org/10.1007/BF00858990 PMID: 7742210

[157] Kielstein, J.T.; Beutel, G.; Fleig, S.; Steinhoff, J.; Meyer, T.N.; Hafer, C.; Kuhlmann, U.; Bramstedt, J.; Panzer, U.; Vischedyk, M.; Busch, V.; Ries, W.; Mitzner, S.; Mees, S.; Stracke, S.; Nürnberger, J.; Gerke, P.; Wiesner, M.; Sucke, B.; Abu-Tair, M.; Kribben, A.; Klause, N.; Schindler, R.; Merkel, F.; Schnatter, S.; Dorresteijn, E.M.; Samuelsson, O.; Brunkhorst, R. Collaborators of the DGfN STEC-HUS registry. Best supportive care and therapeutic plasma exchange with or without eculizumab in Shiga-toxinproducing E. coli O104:H4 induced haemolytic-uraemic syndrome: an analysis of the German STEC-HUS registry. Nephrol. Dial. Transplant., 2012, 27(10), 3807-3815.

http://dx.doi.org/10.1093/ndt/gfs394 PMID: 23114903

[158] Perera, L.P.; Marques, L.R.; O’Brien, A.D. Isolation and characterization of monoclonal antibodies to Shiga-like toxin II of enterohemorrhagic Escherichia coli and use of the monoclonal antibodies in a colony enzyme-linked immunosorbent assay. J. Clin. Microbiol., 1988, 26(10), 2127-2131.

http://dx.doi.org/10.1128/JCM.26.10.2127-2131.1988 PMID: 3053764

[159] Hiriart, Y.; Pardo, R.; Bukata, L.; Lauché, C.; Muñoz, L.; Colonna, M.; Goldbaum, F.; Sanguineti, S.; Zylberman, V. Development of a product anti-Shiga toxin for prevention of the hemolytic uremic syndrome. Medicina (B. Aires), 2018, 78(2), 107-112. PMID: 29659360

[160] Mejías, M.P.; Hiriart, Y.; Lauché, C.; Fernández-Brando, R.J.; Pardo, R.; Bruballa, A.; Ramos, M.V.; Goldbaum, F.A.; Palermo, M.S.; Zylberman, V. Development of camelid single chain antibodies against Shiga toxin type 2 (Stx2) with therapeutic potential against Hemolytic Uremic Syndrome (HUS). Sci. Rep., 2016, 6, 24913 .

http://dx.doi.org/10.1038/srep24913 PMID: 27118524

[161] Kimura, T.; Co, M.S.; Vasquez, M.; Wei, S.; Xu, H.; Tani, S.; Sakai, Y.; Kawamura, T.; Matsumoto, Y.; Nakao, H.; Takeda, T. Development of humanized monoclonal antibody TMA-15 which neutralizes Shiga toxin 2. Hybrid. Hybridomics, 2002, 21(3), 161168.

http://dx.doi.org/10.1089/153685902760173872 PMID: 12165141

[162] Kimura, T.; Tani, S.; Motoki, M.; Matsumoto, Y. Role of Shiga toxin 2 (Stx2)-binding protein, human serum amyloid $\mathrm{P}$ component (HuSAP), in Shiga toxin-producing Escherichia coli infections: assumption from in vitro and in vivo study using HuSAP and antiStx2 humanized monoclonal antibody TMA-15. Biochem. Biophys. Res. Commun., 2003, 305(4), 1057-1060.

http://dx.doi.org/10.1016/S0006-291X(03)00901-X PMID: 12767937

[163] Yamagami, S.; Motoki, M.; Kimura, T.; Izumi, H.; Takeda, T.; Katsuura, Y.; Matsumoto, Y. Efficacy of postinfection treatment with anti-Shiga toxin (Stx) 2 humanized monoclonal antibody TMA-15 in mice lethally challenged with Stx-producing Escherichia coli. J. Infect. Dis., 2001, 184(6), 738-742. http://dx.doi.org/10.1086/323082 PMID: 11517435

[164] Sauter, K.A.; Melton-Celsa, A.R.; Larkin, K.; Troxell, M.L.; O’Brien, A.D.; Magun, B.E. Mouse model of hemolytic-uremic syndrome caused by endotoxin-free Shiga toxin 2 (Stx2) and protection from lethal outcome by anti-Stx2 antibody. Infect. Immun., 2008, 76(10), 4469-4478.

http://dx.doi.org/10.1128/IAI.00592-08 PMID: 18694970

[165] Dowling, T.C.; Chavaillaz, P.A.; Young, D.G.; Melton-Celsa, A.; O’Brien, A.; Thuning-Roberson, C.; Edelman, R.; Tacket, C.O. Phase 1 safety and pharmacokinetic study of chimeric murinehuman monoclonal antibody $\mathrm{c}$ alpha Stx2 administered intravenously to healthy adult volunteers. Antimicrob. Agents Chemother., 2005, 49(5), 1808-1812.
http://dx.doi.org/10.1128/AAC.49.5.1808-1812.2005 PMID: 15855500

[166] Bitzan, M.; Poole, R.; Mehran, M.; Sicard, E.; Brockus, C.; Thuning-Roberson, C.; Rivière, M. Safety and pharmacokinetics of chimeric anti-Shiga toxin 1 and anti-Shiga toxin 2 monoclonal antibodies in healthy volunteers. Antimicrob. Agents Chemother., 2009, 53(7), 3081-3087.

http://dx.doi.org/10.1128/AAC.01661-08 PMID: 19414580

[167] López, E.L.; Contrini, M.M.; Glatstein, E.; González Ayala, S.; Santoro, R.; Allende, D.; Ezcurra, G.; Teplitz, E.; Koyama, T.; Matsumoto, Y.; Sato, H.; Sakai, K.; Hoshide, S.; Komoriya, K.; Morita, T.; Harning, R.; Brookman, S. Safety and pharmacokinetics of urtoxazumab, a humanized monoclonal antibody, against Shigalike toxin 2 in healthy adults and in pediatric patients infected with Shiga-like toxin-producing Escherichia coli. Antimicrob. Agents Chemother. 2010, 54(1), 239-243.

http://dx.doi.org/10.1128/AAC.00343-09 PMID: 19822704

[168] Mejias, M.P.; Cabrera, G.; Fernández-Brando, R.J.; Baschkier, A.; Ghersi, G.; Abrey-Recalde, M.J.; Miliwebsky, E.; Meiss, R.; Goldbaum, F.; Zylberman, V.; Rivas, M.; Palermo, M.S. Protection of mice against Shiga toxin 2 (Stx2)-associated damage by maternal immunization with a Brucella lumazine synthase-Stx2 B subunit chimera. Infect. Immun., 2014, 82(4), 1491-1499.

http://dx.doi.org/10.1128/IAI.00027-14 PMID: 24421050

[169] Mejias, M.P.; Ghersi, G.; Craig, P.O.; Panek, C.A.; Bentancor, L.V.; Baschkier, A.; Goldbaum, F.A.; Zylberman, V.; Palermo, M.S. Immunization with a chimera consisting of the B subunit of Shiga toxin type 2 and brucella lumazine synthase confers total protection against Shiga toxins in mice. J. Immunol., 2013, 191(5), 2403-2411.

http://dx.doi.org/10.4049/jimmunol.1300999 PMID: 23918978

[170] Pandey, K.B.; Rizvi, S.I. Plant polyphenols as dietary antioxidants in human health and disease. Oxid. Med. Cell. Longev., 2009, 2(5), 270-278.

http://dx.doi.org/10.4161/oxim.2.5.9498 PMID: 20716914

[171] Graf, B.A.; Milbury, P.E.; Blumberg, J.B. Flavonols, flavones, flavanones, and human health: epidemiological evidence. J. Med. Food, 2005, 8(3), 281-290.

http://dx.doi.org/10.1089/jmf.2005.8.281 PMID: 16176136

[172] Arts, I.C.; Hollman, P.C. Polyphenols and disease risk in epidemiologic studies. Am. J. Clin. Nutr., 2005, 81(1)(Suppl.), 317S-325S. http://dx.doi.org/10.1093/ajen/81.1.317S PMID: 15640497

[173] Doughari, J.H.; Ndakidemi, P.A.; Human, I.S.; Benade, S. Antioxidant, antimicrobial and antiverotoxic potentials of extracts of Curtisia dentata. J. Ethnopharmacol., 2012, 141(3), 1041-1050. http://dx.doi.org/10.1016/j.jep.2012.03.051 PMID: 22504170

[174] Clifford, M.N.; Jaganath, I.B.; Ludwig, I.A.; Crozier, A. Chlorogenic acids and the acyl-quinic acids: discovery, biosynthesis, bioavailability and bioactivity. Nat. Prod. Rep., 2017, 34(12), 1391-1421.

http://dx.doi.org/10.1039/C7NP00030H PMID: 29160894

[175] Quiñones, B.; Massey, S.; Friedman, M.; Swimley, M.S.; Teter, K. Novel cell-based method to detect Shiga toxin 2 from Escherichia coli $\mathrm{O} 157: \mathrm{H} 7$ and inhibitors of toxin activity. Appl. Environ. Microbiol., 2009, 75(5), 1410-1416. http://dx.doi.org/10.1128/AEM.02230-08 PMID: 19139230

[176] Zhao, T.; Tang, H.; Xie, L.; Zheng, Y.; Ma, Z.; Sun, Q.; Li, X. Scutellaria baicalensis Georgi. (Lamiaceae): a review of its traditional uses, botany, phytochemistry, pharmacology and toxicology. J. Pharm. Pharmacol., 2019, 71(9), 1353-1369. http://dx.doi.org/10.1111/jphp.13129 PMID: 31236960

[177] Tao, Y.; Zhan, S.; Wang, Y.; Zhou, G.; Liang, H.; Chen, X.; Shen, H. Baicalin, the major component of traditional Chinese medicine Scutellaria baicalensis induces colon cancer cell apoptosis through inhibition of oncomiRNAs. Sci. Rep., 2018, 8(1), 14477. http://dx.doi.org/10.1038/s41598-018-32734-2 PMID: 30262902

[178] Dong, J.; Zhang, Y.; Chen, Y.; Niu, X.; Zhang, Y.; Yang, C.; Wang, Q.; Li, X.; Deng, X. Baicalin inhibits the lethality of Shigalike toxin 2 in mice. Antimicrob. Agents Chemother., 2015, 59(11), 7054-7060.

http://dx.doi.org/10.1128/AAC.01416-15 PMID: 26349825

[179] Zhang, Y.; Qi, Z.; Liu, Y.; He, W.; Yang, C.; Wang, Q.; Dong, J.; Deng, $\mathrm{X}$. Baicalin protects mice from lethal infection by enterohemorrhagic Escherichia coli. Front. Microbiol., 2017, 8, 395. http://dx.doi.org/10.3389/fmicb.2017.00395 PMID: 28337193 
[180] Vinh, P.T.; Shinohara, Y.; Yamada, A.; Duc, H.M.; Nakayama, M.; Ozawa, T.; Sato, J.; Masuda, Y.; Honjoh, K.I.; Miyamoto, T. Baicalein Inhibits Stx 1 and 2 of EHE: Effects of baicalein on the cytotoxicity, production, and secretion of Shiga Toxins of Enterohaemorrhagic Escherichia coli. Toxins (Basel), 2019, 11(9), E505. http://dx.doi.org/10.3390/toxins11090505 PMID: 31470657

[181] Sugita-Konishi, Y.; Hara-Kudo, Y.; Amano, F.; Okubo, T.; Aoi, N.; Iwaki, M.; Kumagai, S. Epigallocatechin gallate and gallocatechin gallate in green tea catechins inhibit extracellular release of Vero toxin from enterohemorrhagic Escherichia coli O157:H7. Biochim. Biophys. Acta, 1999, 1472(1-2), 42-50.

http://dx.doi.org/10.1016/S0304-4165(99)00102-6 PMID: 10572924

[182] Higdon, J.V.; Frei, B. Tea catechins and polyphenols: health effects, metabolism, and antioxidant functions. Crit. Rev. Food Sci. Nutr., 2003, 43(1), 89-143.

http://dx.doi.org/10.1080/10408690390826464 PMID: 12587987

[183] Fan, F.Y.; Sang, L.X.; Jiang, M. Catechins and their therapeutic benefits to inflammatory bowel disease. Molecules, 2017, 22(3), E484.

http://dx.doi.org/10.3390/molecules22030484 PMID: 28335502

[184] Miyamoto, T. Specific inhibition of cytotoxicity of Shiga-like toxin 1 of enterohemorrhagic Escherichia coli by gallocatechin gallate and epigallocatechin gallate. Food Control, 2014, 42, 263-269. http://dx.doi.org/10.1016/j.foodcont.2014.02.017

[185] Toda, M.; Okubo, S.; Ikigai, H.; Suzuki, T.; Suzuki, Y.; Shimamura, T. The protective activity of tea against infection by Vibrio cholerae O1. J. Appl. Bacteriol., 1991, 70(2), 109-112. http://dx.doi.org/10.1111/j.1365-2672.1991.tb04435.x PMID: 2019547

[186] Toda, M.; Okubo, S.; Ohnishi, R.; Shimamura, T. Antibacterial and bactericidal activities of Japanese green tea. Nippon Saikingaku Zasshi, 1989, 44(4), 669-672.

http://dx.doi.org/10.3412/jsb.44.669 PMID: 2677434

[187] Nakayama, M.; Suzuki, K.; Toda, M.; Okubo, S.; Hara, Y.; Shimamura, T. Inhibition of the infectivity of influenza virus by tea polyphenols. Antiviral Res., 1993, 21(4), 289-299.

http://dx.doi.org/10.1016/0166-3542(93)90008-7 PMID: 8215301

[188] Guo, Q.; Zhao, B.; Li, M.; Shen, S.; Xin, W. Studies on protective mechanisms of four components of green tea polyphenols against lipid peroxidation in synaptosomes. Biochim. Biophys. Acta, 1996, 1304(3), 210-222.

http://dx.doi.org/10.1016/S0005-2760(96)00122-1 PMID: 8982267

[189] Sanders, M.E. Probiotics in 2015: Their scope and use. J. Clin. Gastroenterol., 2015, 49(Suppl. 1), S2-S6.

http://dx.doi.org/10.1097/MCG.0000000000000350 PMID: 26447958

[190] Holscher, H.D. Dietary fiber and prebiotics and the gastrointestinal microbiota. Gut Microbes, 2017, 8(2), 172-184. http://dx.doi.org/10.1080/19490976.2017.1290756 PMID: 28165863

[191] Gibson, G.R.; Roberfroid, M.B. Dietary modulation of the human colonic microbiota: introducing the concept of prebiotics. J. Nutr., 1995, 125(6), 1401-1412.

http://dx.doi.org/10.1093/jn/125.6.1401 PMID: 7782892

[192] Ridley, B.L.; O’Neill, M.A.; Mohnen, D. Pectins: structure, biosynthesis, and oligogalacturonide-related signaling. Phytochemistry, 2001, 57(6), 929-967.

http://dx.doi.org/10.1016/S0031-9422(01)00113-3 PMID: 11423142

[193] Olano-Martin, E.; Williams, M.R.; Gibson, G.R.; Rastall, R.A. Pectins and pectic-oligosaccharides inhibit Escherichia coli O157:H7 Shiga toxin as directed towards the human colonic cell line HT29. FEMS Microbiol. Lett., 2003, 218(1), 101-105. http://dx.doi.org/10.1111/j.1574-6968.2003.tb11504.x PMID: 12583904

[194] Di, R.; Vakkalanka, M.S.; Onumpai, C.; Chau, H.K.; White, A.; Rastall, R.A.; Yam, K.; Hotchkiss, A.T., Jr Pectic oligosaccharide structure-function relationships: Prebiotics, inhibitors of Escherichia coli $\mathrm{O} 157: \mathrm{H} 7$ adhesion and reduction of Shiga toxin cytotoxicity in HT29 cells. Food Chem., 2017, 227, 245-254. http://dx.doi.org/10.1016/j.foodchem.2017.01.100 PMID: 28274429

[195] Hill, C.; Guarner, F.; Reid, G.; Gibson, G.R.; Merenstein, D.J.; Pot, B.; Morelli, L.; Canani, R.B.; Flint, H.J.; Salminen, S.; Calder,
P.C.; Sanders, M.E. Expert consensus document. The International Scientific Association for Probiotics and Prebiotics consensus statement on the scope and appropriate use of the term probiotic. Nat. Rev. Gastroenterol. Hepatol., 2014, 11(8), 506-514. http://dx.doi.org/10.1038/nrgastro.2014.66 PMID: 24912386

[196] Williams, N.T. Probiotics. Am. J. Health Syst. Pharm., 2010, 67(6), 449-458.

http://dx.doi.org/10.2146/ajhp090168 PMID: 20208051

[197] Mohsin, M.; Guenther, S.; Schierack, P.; Tedin, K.; Wieler, L.H. Probiotic Escherichia coli Nissle 1917 reduces growth, Shiga toxin expression, release and thus cytotoxicity of enterohemorrhagic Escherichia coli. Int. J. Med. Microbiol., 2015, 305(1), 20-26. http://dx.doi.org/10.1016/j.ijmm.2014.10.003 PMID: 25465158

[198] Rund, S.A.; Rohde, H.; Sonnenborn, U.; Oelschlaeger, T.A. Antagonistic effects of probiotic Escherichia coli Nissle 1917 on EHEC strains of serotype O104:H4 and O157:H7. Int. J. Med. Microbiol., 2013, 303(1), 1-8. http://dx.doi.org/10.1016/j.ijmm.2012.11.006 PMID: 23312798

[199] Reissbrodt, R.; Hammes, W.P.; dal Bello, F.; Prager, R.; Fruth, A.; Hantke, K.; Rakin, A.; Starcic-Erjavec, M.; Williams, P.H. Inhibition of growth of Shiga toxin-producing Escherichia coli by nonpathogenic Escherichia coli. FEMS Microbiol. Lett., 2009, 290(1), 62-69.

http://dx.doi.org/10.1111/j.1574-6968.2008.01405.x PMID: 19016876

[200] Kushida, Y; Wakao, S.; Dezawa, M. Muse cells are endogenous reparative stem cells. Adv. Exp. Med. Biol., 2018, 1103, 43-68. http://dx.doi.org/10.1007/978-4-431-56847-6_3 PMID: 30484223

[201] Dezawa, M. Clinical trials of muse cells. $\bar{A} d v$. Exp. Med. Biol., 2018, 1103, 305-307.

http://dx.doi.org/10.1007/978-4-431-56847-6_17 PMID: 30484237

[202] Ozuru, R. Rescue from Stx2-Producing E.coli-Associated encephalopathy by intravenous injection of muse cells in NOD-SCID Mice. Mol. Ther., 2019, 28,100-118.

PMID: 31607541

[203] Chu, H.; Tang, Y.; Dong, Q. Protection of granulocyte-colony stimulating factor to hemorrhagic brain injuries and its involved mechanisms: effects of vascular endothelial growth factor and aquaporin-4. Neuroscience, 2014, 260, 59-72.

http://dx.doi.org/10.1016/j.neuroscience.2013.12.017 PMID: 24355496

[204] Dietrich, J.; Baryawno, N.; Nayyar, N.; Valtis, Y.K.; Yang, B.; Ly, I.; Besnard, A.; Severe, N.; Gustafsson, K.U.; Andronesi, O.C.; Batchelor, T.T.; Sahay, A.; Scadden, D.T. Bone marrow drives central nervous system regeneration after radiation injury. J. Clin. Invest., 2018, 128(6), 2651.

http://dx.doi.org/10.1172/JCI121592 PMID: 29856368

[205] Hattori, T.; Watanabe-Takahashi, M.; Ohoka, N.; Hamabata, T.; Furukawa, K.; Nishikawa, K.; Naito, M. Proteasome inhibitors prevent cell death and prolong survival of mice challenged by Shiga toxin. FEBS Open Bio, 2015, 5, 605-614. http://dx.doi.org/10.1016/j.fob.2015.06.005 PMID: 26273560

[206] Silberstein, C.; Lucero, M.S.; Zotta, E.; Copeland, D.P.; Lingyun, L.; Repetto, H.A.; Ibarra, C. A glucosylceramide synthase inhibitor protects rats against the cytotoxic effects of shiga toxin 2. Pediatr. Res., 2011, 69(5 Pt 1), 390-394. http://dx.doi.org/10.1203/PDR.0b013e318211dd57 PMID: 21270676

[207] Flam, B.; Sackey, P.; Berge, A.; Zachau, A.C.; Brink, B.; Lundberg, S. Diarrhea-associated hemolytic uremic syndrome with severe neurological manifestations treated with $\mathrm{IgG}$ depletion through immunoadsorption. J. Nephrol., 2016, 29(5), 711-714. http://dx.doi.org/10.1007/s40620-016-0294-5 PMID: 26995001

[208] Bergan, J.; Skotland, T.; Lingelem, A.B.; Simm, R.; Spilsberg, B.; Lindbäck, T.; Sylvänne, T.; Simolin, H.; Ekroos, K.; Sandvig, K. The ether lipid precursor hexadecylglycerol protects against Shiga toxins. Cell. Mol. Life Sci., 2014, 71(21), 4285-4300. http://dx.doi.org/10.1007/s00018-014-1624-1 PMID: 24740796

[209] Ailte, I.; Lingelem, A.B.; Kavaliauskiene, S.; Bergan, J.; Kvalvaag, A.S.; Myrann, A.G.; Skotland, T.; Sandvig, K. Addition of lysophospholipids with large head groups to cells inhibits Shiga toxin binding. Sci. Rep., 2016, 6, 30336.

http://dx.doi.org/10.1038/srep30336 PMID: 27458147

[210] Stechmann, B.; Bai, S.K.; Gobbo, E.; Lopez, R.; Merer, G.; Pinchard, S.; Panigai, L.; Tenza, D.; Raposo, G.; Beaumelle, B.; 
Sauvaire, D.; Gillet, D.; Johannes, L.; Barbier, J. Inhibition of retrograde transport protects mice from lethal ricin challenge. Cell, 2010, 141(2), 231-242.

http://dx.doi.org/10.1016/j.cell.2010.01.043 PMID: 20403321

[211] Abdelkafi, H.; Michau, A.; Clerget, A.; Buisson, D.A.; Johannes, L.; Gillet, D.; Barbier, J.; Cintrat, J.C. Synthesis, chiral separation, absolute configuration assignment, and biological activity of enantiomers of retro- 1 as potent inhibitors of Shiga Toxin. ChemMedChem, 2015, 10(7), 1153-1156.

http://dx.doi.org/10.1002/cmdc.201500139 PMID: 26033849

[212] Secher, T.; Shima, A.; Hinsinger, K.; Cintrat, J.C.; Johannes, L.; Barbier, J.; Gillet, D.; Oswald, E. Retrograde trafficking inhibitor of shiga toxins reduces morbidity and mortality of mice infected with enterohemorrhagic Escherichia coli. Antimicrob. Agents Chemother., 2015, 59(8), 5010-5013.

http://dx.doi.org/10.1128/AAC.00455-15 PMID: 25987610

[213] Gupta, N.; Noël, R.; Goudet, A.; Hinsinger, K.; Michau, A.; Pons, V.; Abdelkafi, H.; Secher, T.; Shima, A.; Shtanko, O.; Sakurai, Y.; Cojean, S.; Pomel, S.; Liévin-Le Moal, V.; Leignel, V.; Herweg, J.A.; Fischer, A.; Johannes, L.; Harrison, K.; Beard, P.M.; Clayette, P.; Le Grand, R.; Rayner, J.O.; Rudel, T.; Vacus, J.; Loiseau, P.M.; Davey, R.A.; Oswald, E.; Cintrat, J.C.; Barbier, J.; Gillet, D. Inhibitors of retrograde trafficking active against ricin and Shiga toxins also protect cells from several viruses, Leishmania and Chlamydiales. Chem. Biol. Interact., 2017, 267, 96-103. http://dx.doi.org/10.1016/j.cbi.2016.10.005 PMID: 27712998

[214] de Vries Schultink, A.H.; Zwart, W.; Linn, S.C.; Beijnen, J.H.; Huitema, A.D. Effects of pharmacogenetics on the pharmacokinetics and pharmacodynamics of tamoxifen. Clin. Pharmacokinet., 2015, 54(8), 797-810.

http://dx.doi.org/10.1007/s40262-015-0273-3 PMID: 25940823

[215] Touitou, I.; Mathieu, M.; Rochefort, H. Stable transfection of the estrogen receptor cDNA into Hela cells induces estrogen responsiveness of endogenous cathepsin D gene but not of cell growth. Biochem. Biophys. Res. Commun., 1990, 169(1), 109-115.
http://dx.doi.org/10.1016/0006-291X(90)91440-4 PMID: 2350335

[216] Paton, J.C.; Paton, A.W. Pathogenesis and diagnosis of Shiga toxin-producing Escherichia coli infections. Clin. Microbiol. Rev., 1998, 11(3), 450-479.

http://dx.doi.org/10.1128/CMR.11.3.450 PMID: 9665978

[217] Selyunin, A.S. Tamoxifen blocks retrograde trafficking of Shiga toxin 1 and 2 and protects against lethal toxicosis. Life Sci Alliance, 2019, 2(3).

http://dx.doi.org/10.26508/lsa.201900439

[218] Pitz, A.M.; Park, G.W.; Lee, D.; Boissy, Y.L.; Vinjé, J. Antimicrobial activity of bismuth subsalicylate on Clostridium difficile, Es cherichia coli O157:H7, norovirus, and other common enteric pathogens. Gut Microbes, 2015, 6(2), 93-100. http://dx.doi.org/10.1080/19490976.2015.1008336 PMID: 25901890

[219] Subils, T.; Casabonne, C.; Balagué, C. The inhibitory effect of colloidal bismuth hydroxide gel on Escherichia coli $\mathrm{O} 157: \mathrm{H} 7$ and on the activity of Shiga toxins. BMC Res. Notes, 2014, 7, 875 http://dx.doi.org/10.1186/1756-0500-7-875 PMID: 25475210

[220] Crane, J.K.; Broome, J.E.; Reddinger, R.M.; Werth, B.B. Zinc protects against Shiga-toxigenic Escherichia coli by acting on host tissues as well as on bacteria. BMC Microbiol., 2014, 14, 145. http://dx.doi.org/10.1186/1471-2180-14-145 PMID: 24903402

[221] Tewari, R.; Jarvela, T.; Linstedt, A.D. Manganese induces oligomerization to promote down-regulation of the intracellular trafficking receptor used by Shiga toxin. Mol. Biol. Cell, 2014, 25(19), 3049-3058.

http://dx.doi.org/10.1091/mbc.e14-05-1003 PMID: 25079690

[222] Trachtman, H.; Cnaan, A.; Christen, E.; Gibbs, K.; Zhao, S.; Acheson, D.W.; Weiss, R.; Kaskel, F.J.; Spitzer, A.; Hirschman, G.H. Investigators of the HUS-SYNSORB Pk Multicenter Clinical Trial. Effect of an oral Shiga toxin-binding agent on diarrhea-associated hemolytic uremic syndrome in children: a randomized controlled trial. JAMA, 2003, 290(10), 1337-1344.

http://dx.doi.org/10.1001/jama.290.10.1337 PMID: 12966125 